\title{
The publications of Ramon Margalef in Investigación Pesquera and Scientia Marina: The beginnings of marine ecology in the CSIC
}

\author{
Marta Estrada ${ }^{1}$, Miquel Alcaraz ${ }^{2}$ \\ ${ }^{1}$ Institut de Ciències del Mar, CSIC, Pg. Marítim de la Barceloneta, 37-49, 08003 Barcelona, Spain. \\ (ME) E-mail: marta@icm.csic.es. ORCID ID: https://orcid.org/0000-0001-5769-9498 \\ ${ }^{2}$ Associació Mar de Ciència, ICM, P. Marítim de la Barceloneta 37-49, 08003 Barcelona, Spain. \\ (MA) E-mail: miquel@icm.csic.es. ORCID ID: https://orcid.org/0000-0002-4803-2306
}

\begin{abstract}
Summary: Ramon Margalef López (1919-2004) was one of the most prominent scientists of the 20th century in the fields of limnology, oceanography and ecology. His contributions to theoretical ecology, which won him international recognition, were based on a great deal of laboratory and field work and on extensive observations of the natural world, a passion that he acquired at a young age. Some of the early papers of Ramon Margalef appeared in the Publicaciones del Instituto de Biología Aplicada, but as of 1955 many of his marine studies were published in Investigación Pesquera, the journal of the Instituto de Investigaciones Pesqueras of the CSIC in Barcelona. He also wrote several articles for Scientia Marina, the journal that replaced Investigación Pesquera in 1989 after the Instituto de Investigaciones Pesqueras became the Institut de Ciències del Mar. The present article aims to give an overview of Margalef's contributions to these journals to mark the celebration in 2019 of the 100th anniversary of his birth.
\end{abstract}

Keywords: Ramon Margalef; Investigación Pesquera; Scientia Marina, publications; naturalist; physical models.

Las publicaciones de Ramón Margalef en Investigación Pesquera y Scientia Marina: Los comienzos de la ecología marina en el CSIC

Resumen: Ramon Margalef López (1919-2004) fue uno de los científicos más destacados del siglo XX en los campos de la limnología, la oceanografía y la ecología. Sus contribuciones a la ecología teórica, que le valieron el reconocimiento internacional, se basaron en una gran cantidad de trabajo en el campo y en el laboratorio, y en extensivas observaciones del mundo natural, una pasión que adquirió a una edad temprana. Algunos de los primeros artículos de Ramon Margalef aparecieron en las Publicaciones del Instituto de Biología Aplicada pero, después de 1955, muchos de sus trabajos marinos se publicaron en Investigación Pesquera, la revista del Instituto de Investigaciones Pesqueras del CSIC en Barcelona. También escribió varios artículos para Scientia Marina, la revista que sucedió a Investigación Pesquera en 1989, después de que el Instituto de Investigaciones Pesqueras se convirtiera en el Institut de Ciències del Mar. El presente escrito tiene como objetivo dar una visión general de las contribuciones de Margalef a estas revistas, en el contexto de la reciente celebración (2019) del centenario de su nacimiento.

Palabras clave: Ramón Margalef; Investigación Pesquera; Scientia Marina; publicaciones; naturalista; modelos físicos.

Citation/Como citar este artículo: Estrada M., Alcaraz M. 2020. The publications of Ramon Margalef in Investigación Pesquera and Scientia Marina: The beginnings of marine ecology in the CSIC. Sci. Mar. 84(4): 445-461. https://doi.org/10.3989/ scimar.05107.30A

Editor: F. Peters.

Received: July 22, 2020. Accepted: October 16, 2020. Published: November 10, 2020.

Copyright: $\odot 2020$ CSIC. This is an open-access article distributed under the terms of the Creative Commons Attribution 4.0 International (CC BY 4.0) License.

\section{INTRODUCTION}

Ramon Margalef López (1919-2004) was a pioneer who made outstanding scientific contributions in limnology, oceanography and ecology. He was an exceptional scientist, teacher and mentor and is considered one of the founding fathers of modern ecological theory. However, he often qualified himself as a naturalist and grounded his thinking on long hours of painstaking observation of nature accompanied by field work and imaginative 
experiments. Much of this activity was carried out in Barcelona, at the Instituto de Investigaciones Pesqueras (Institute of Fisheries Research, IIP) of the Consejo Superior de Investigaciones Científicas (Spanish National Research Council, CSIC), now renamed Institut de Ciències del Mar (Institute of Marine Sciences, ICM). As part of the celebration of the 100th anniversary of Margalef's birth, this article aims to give an overview of his contributions to the journal Investigación Pesquera and to its successor, Scientia Marina.

\section{BIOGRAPHICAL CONTEXT}

This section will provide only a brief account of the unusual career path of Ramon Margalef. More detailed explanations of his biography and thinking can be found in publications such as Bonnín (1994), Durfort (2005), Peters (2010) and in numerous interviews and press articles.

From a very young age, Margalef was an enthusiastic observer of nature, in particular of aquatic organisms, and as a teenager he continued with his selftaught naturalist studies. In 1938, two years after the Spanish Civil War broke out, Margalef was conscripted into the Republican Army. After the end of the war, he was drafted again, this time to serve on the winning Nationalist side until 1943. Margalef persisted with his scientific observations and his merits were recognized by influential scientists and naturalists in Catalonia, who encouraged him to study Natural Sciences at the University of Barcelona, where he graduated in 1949. In the same year the CSIC created the Marine Biology Section of the Instituto de Biología Aplicada (Institute of Applied Biology, IBA), which in 1951 became the IIP, under the direction of Francisco García del Cid. Margalef, who had obtained his doctoral degree in 1951, joined the IIP as a researcher in 1952. After the sudden death of García del Cid in 1965, Margalef became director of the IIP and served in this position until 1967, when he occupied the first Ecology chair in Spain at the University of Barcelona. He retained a part-time position at the IIP until he was forced to give it up in 1977. He retired officially in 1993, but continued his scientific work until the last years of his life. He died in 2004, having authored several books and nearly 600 publications, $87 \%$ of which are single-authored, and in only $3.9 \%$ he is not the first author (Peters 2010).

Margalef's initial work as a naturalist dealt mainly with observation of organisms of continental waters, a passion that he kept throughout his life. After his engagement at the IBA, he started studying the marine ecosystem. As he wrote in an unpublished autobiography (Margalef 2004):

"La vida aquàtica apareix dividida en... dos reialmes $i$ aquesta situació resulta força interessant per aprendre aspectes de la interacció entre el medi intern i l'entorn de la vida... una cama o peu en cadascun dels grans sistemes aquàtics del planeta... enriquia qualsevol estudi comparat". ("Aquatic life is divided into... two realms and this situation is quite interesting to learn aspects of the interaction between the internal environment and the environment of life... a leg or foot on each of the great aquatic systems on the planet... would enrich any comparative study").

Both as a limnologist and as an oceanographer, Margalef's observations built the taxonomic basis for the scientific study of planktonic organisms in Spain. However, in parallel with this descriptive effort, Margalef strived to deepen his understanding of the relationships between hydrographic factors and plankton ecophysiology and to find general principles underlying phytoplankton diversity and succession. From the beginning of his scientific career and throughout his life, Margalef assembled a theoretical framework that made him one of the most influential ecologists of our times. Some of Margalef's best known early theoretical contributions appeared in English in books (Margalef 1968 and Margalef 1997b) and international journals, but the fundamentals for many of them could be found in the publications of the IIP.

A number of Margalef's early publications (between 1944 and 1958; Table 1), mostly on continental waters but also on marine phytoplankton, appeared in the journal of the IBA, Publicaciones del Instituto de Biología Aplicada, which was discontinued in 1973. After the appearance of Investigación Pesquera, in 1955, Margalef contributed 65 articles to this journal between then and 1972 (averaging more than three papers per year) and one in 1987 (Table 2). The In-

Table 1. - Publications of Ramon Margalef dealing with marine science in Publicaciones del Instituto de Biología Aplicada, arranged chronologically.

\begin{tabular}{|c|c|}
\hline Title & Reference \\
\hline Fitoplancton nerítico estival de Cadaqués (Mediterráneo catalán). & Margalef 1945-1946 \\
\hline Fitoplancton nerítico de la Costa Brava en 194748. & Margalef 1948-1949 \\
\hline Plancton recogido por los laboratorios costeros, I. Plancton de Blanes durante el verano de 1949. & Margalef 1950 \\
\hline Diversidad de especies en las comunidades naturales. & Margalef 1951a \\
\hline Plancton recogido por los laboratorios costeros, III. Plancton de las costas de Castellón durante el año 1950. & Margalef 1951b \\
\hline Ciclo anual del fitoplancton marino en la costa NE de la Península Ibérica. & Margalef 1951c \\
\hline Datos para una crítica del significado de la media vertebral de las poblaciones de la sardina (Sardina pilchardus Walb.). & Rodríguez-Roda et al. 1951 \\
\hline Plancton recogido por los laboratorios costeros, V.- Fitoplancton de las costas de Castellón durante el año 1951. & Margalef et al. 1952 \\
\hline Estudios experimentales sobre las modificaciones inducidas por diferentes temperaturas en células de clorofíceas. & Margalef $1953 \mathrm{a}$ \\
\hline Caracteres ligados a las magnitudes de los organismos y su significado sistemático y evolutivo. & Margalef $1953 \mathrm{~b}$ \\
\hline Microplancton de Vigo, de octubre de 1951 a septiembre de 1952. & Margalef and Durán 1953 \\
\hline $\begin{array}{l}\text { Consideraciones sobre la determinación cuantitativa del fitoplancton por la valoración de pigmentos solubles } \\
\text { y los factores que afectan a la relación entre cantidad de pigmento y peso seco. }\end{array}$ & Margalef $1954 \mathrm{a}$ \\
\hline Un aparato para el cultivo de algas en condiciones regulables. & Margalef 1954b \\
\hline Plancton recogido por los laboratorios costeros. VIII. Fitoplancton de las costas de Castellón durante el año 1952. & Margalef et al. 1954 \\
\hline Una técnica de filtración para el estudio cualitativo y cuantitativo del fitoplancton. & Margalef $1954 \mathrm{c}$ \\
\hline Temperatura, dimensiones y evolución. & Margalef 1955 \\
\hline
\end{tabular}


Table 2. - Publications of Ramon Margalef in Investigación Pesquera, arranged chronologically.

Title

Fitoplancton de las costas de Castellón durante el año 1953.

El fitoplancton de la ría de Vigo de enero de 1953 a marzo de 1954.

Cultivos experimentales de algas unicelulares.

Información y diversidad específica en las comunidades de organismos.

El fitoplancton de la ría de Vigo, de abril de 1954 a junio de 1955.

Rotíferos marinos del plancton de la ría de Vigo.

Paleoecología postglacial de la ría de Vigo.

Estructura y dinámica de la "purga de mar" en la ría de Vigo.

Fitoplancton de las costas de Castellón durante el año 1954.

Hidrografía y fitoplancton de las costas de Castellón, de julio de 1956 a junio de 1957.

Fitoplancton de las costas de Puerto Rico.

Nuevos aspectos del problema de la suspensión en los organismos planctónicos.

Un modelo para el estudio de la distribución de organismos de gran dispersabilidad y área de reproducción muy localizada.

Fitoplancton de las costas de Blanes (Gerona) de agosto de 1952 a junio de 1956.

Variación local e interanual en la secuencia de las poblaciones de fitoplancton de red en las aguas superficiales de la costa mediterránea española.

Fitoplancton de las costas de Castellón de enero de 1955 a junio de 1956.

La sedimentación orgánica y la vida en los fondos fangosos de la ría de Vigo.

Componente vertical de los movimientos del agua en la ria deVigo y su posible relación con la entrada de la sardina.

Hidrografía y fitoplancton de las costas de Castellón, de julio de 1957 a junio de 1958.

Pigmentos asimiladores extraídos de las colonias de celentéreos de los arrecifes de coral y su significado ecológico.

Fitoplancton de las costas de Blanes (Gerona), de julio de 1956 a junio de 1959.

Hidrografía y fitoplancton de las costas de Castellón, de julio de 1958 a junio de 1959

Velocidad de sedimentación de organismos pasivos del fitoplancton.

Hidrografía y fitoplancton de un área marina de la costa meridional de Puerto Rico.

El nivel del mar en Castellón.

Distribución ecológica y geográfica de las especies del fitoplancton marino.

Variaciones intraespecíficas de los pigmentos asimiladores en clorofíceas y fanerógamas acuáticas.

Fitoplancton atlántico de las costas de Mauritania y Senegal.

Hidrografía y fitoplancton de la costa comprendida entre Castellón y la desembocadura del Ebro, de julio de 1960 a junio de 1961

Hidrografía y fitoplancton de las costas de Castellón, de julio de 1959 a junio de 1960.

Desarrollo experimental de picnoclinas en pequeños volúmenes de agua.

Modelos simplificados del ambiente marino para el estudio de la sucesión y distribución del fitoplancton y del valor indicador de sus pigmentos.

Algunas regularidades en la distribución a escala pequeña y media de las poblaciones marinas de fitoplancton y en sus características funcionales.

Fitoplancton e hidrografía de las costas de Cádiz (Barbate), de junio de 1961 a agosto de 1962.

Hidrografía y fitoplancton de la costa comprendida entre Castellón y la desembocadura del Ebro, de julio de 1961 a julio de 1962.

Fitoplancton de las costas de Blanes (Provincia de Gerona, Mediterráneo occidental), de julio de 1959 a junio de 1963.

Modelos experimentales de poblaciones de fitoplancton: nuevas observaciones sobre pigmentos y fijación de carbono inorgánico.

Distribución ecológica de las especies del fitoplancton marino en un área del Mediterráneo Occidental.

Estimación de la actividad total añadida y de la autoabsorción en las determinaciones de producción del fitoplancton con ${ }^{14} \mathrm{C}$.

La producción primaria en las aguas del puerto de Barcelona.

Correlaciones entre parámetros oceanográficos del Caribe.

Fitoplancton y producción primaria de la costa catalana, de junio de 1965 a junio de 1966.

Significado de las diferencias verticales de potencial eléctrico en el mar.

Un ejemplo de diversidad química.

Fitoplancton y producción primaria de la costa catalana, de julio de 1966 a julio de 1967.

Experiencias con contadores de seston en el crucero del "Mechelen", "Mediterranean outflow 1965", y formas de elaborar los resultados.

Grupos de especies asociadas en el fitoplancton del Mar Caribe (NE de Venezuela).

Composición específica del fitoplancton de la costa catalano-levantina (Mediterráneo Occidental) en 1962-1967.

Diversidad del fitoplancton de red en dos áreas del Atlántico.

Seminario de Ecología Matemática.

Diversidad y productividad del fitoplancton en el Mediterráneo Occidental.

Influencia del puerto de Barcelona sobre el fitoplancton de las áreas vecinas: Una mancha de plancton de gran densidad, con dominancia de Thalassiosira, observada en agosto de 1969.

Una campaña oceanográfica del "Cornide de Saavedra" en la región de afloramiento de noroeste africano.

Simple approaches to a pattern analysis of phytoplankton.

Distribución del fitoplancton entre Córcega y Barcelona, en relación con la mezcla vertical del agua, en marzo de 1970.

Editorial. Seminario sobre análisis factorial en ecología y taxonomía.

Interpretaciones no estrictamente estadísticas de la representación de entidades biológicas en un espacio multifactorial.

Regularidades en la distribución de la diversidad del fitoplancton en un área del mar Caribe.

Some critical remarks on the usual approaches to ecological modelling.

Alternative approaches in the modelling of populations.

Synoptic distribution of summer microplankton (Algae and Protozoa) across the principal front in the western Mediterranean.
Reference

Herrera et al. 1955

Margalef et al. 1955

Margalef 1956a

Margalef $1956 \mathrm{~b}$

Durán et al. 1956

Margalef $1956 \mathrm{c}$

Margalef 1956d

Margalef 1956e

Muñoz et al. 1956

Herrera and Margalef 1957

Margalef 1957a

Margalef 1957b

Margalef 1957c

Margalef 1957d

Margalef 1957e

Margalef et al. 1957

Margalef 1958a

Margalef and Andreu 1958

Margalef et al. 1959

Margalef 1959

Margalef and Morales 1960

Herrera and Margalef 1961

Margalef 1961a

Margalef 1961b

Margalef and Herrera 1961

Margalef 1961c

Margalef 1961d

Margalef 1961e

Herrera and Margalef 1963

Margalef and Herrera 1963

Margalef 1963a

Margalef 1963b

Margalef 1963c

Establier and Margalef 1964

Margalef and Herrera 1964

Margalef 1964a

Margalef 1964b

Margalef 1965

Herrera and Margalef 1966

Margalef and Herrera 1966

Margalef 1967a

Margalef and Ballester 1967

Margalef 1967b

Margalef 1967c

Margalef and Castellví 1967

Margalef 1967d

Margalef and González

Bernáldez 1969

Margalef 1969a

Margalef 1969b

Margalef 1970a

Margalef 1970b

Margalef and Blasco 1970

Margalef 1971a

Margalef and Estrada 1971

Margalef 1971b

Margalef 1972a

Margalef 1972b

Margalef 1972c

Margalef 1973

Margalef 1979

Margalef and Estrada 1987 
Table 3. - Publications of Ramon Margalef in Scientia Marina (Sci. Mar.).

\begin{tabular}{l} 
Title \\
Through the looking glass: How marine phytoplankton appears through the microscope when graded by size and Margalef 1994 \\
taxonomically sorted. \\
Turbulence and marine life. \\
The top layers of water bodies, a most important although relatively neglected piece of the biosphere plumbing. \\
\hline
\end{tabular}

vestigación Pesquera series also included several monographic issues dealing with meetings or seminars organized by Margalef: the Seminar on Mathematical Ecology (Margalef 1970a), the Working Conference on Analysis of Upwelling Systems (held in March 1970), whose papers were published in Investigación Pesquera 35(1), and the Seminar on Factor Analysis in Ecology and Taxonomy (Margalef 1972a). Margalef also contributed to Scientia Marina (in 1994, 1997 and 2001; Table 3), which replaced Investigación Pesquera in 1989 (see Lleonart and Olivar 2011 for a history of these journals) after the IIP became the ICM. As was required at the time, all articles by Margalef in Publicaciones del Instituto de Biología Aplicada and most in Investigación Pesquera were written in Spanish [exceptions were Margalef and Estrada (1971) and the last two, Margalef (1979), Margalef and Estrada (1987)]. Those in Scientia Marina were in English. In addition to his publications in Investigación Pesquera, Scientia Marina and many other Spanish and international journals (see Peters 2010 for a comprehensive list), Margalef also contributed to sister publications of Investigación Pesquera at the IIP, such as Resultados de Expediciones, Suplemento de Investigación Pesquera (from its beginning in 1972 until 1979, the title was Resultados de Expediciones Científicas del Buque Oceanográfico Cornide de Saavedra. Suplemento de Investigación Pesquera), for which he wrote six papers between 1972 and 1975, and the proceedings of the Productivity and Fisheries Meetings, a series of seminars organized by the IIP, which appeared in specific publications in 1954, 1955, 1957, 1960 and 1965.

The objective of this article is to present a brief overview of the published contribution of Margalef to Publicaciones del Instituto de Biología Aplicada, Investigación Pesquera and Scientia Marina. In order to do this, we propose a rough classification into four main aspects covered in these articles: Margalef as a naturalist; Margalef as a scientific illustrator; physical models and "rain-making" machines; and theoretical ecology. This arrangement should be considered only as an operative approximation, because, from the beginning of his career, one of the characteristics of Margalef's scientific thinking was his integrative and multidisciplinary approach. In addition, he would often revisit and rework previously established concepts.

\section{MARGALEF AS A NATURALIST}

\section{Seasonal cycles and time series of phytoplankton, large scale oceanographic studies (upwelling regions), phytoplankton life-forms and external energy}

We consider in this section the articles focusing on the taxonomic description and spatio-temporal dis- tribution of phytoplankton at coastal stations and on large-scale cruises.

Margalef's first marine phytoplankton studies [Margalef 1945, 1948 (although the volumes appeared one year later), Margalef 1951b] dealt with net tows in different parts of the Catalan coast and were mainly concerned with compiling a list of species, with associated morphological and habitat data. Between 1950 and 1970, Margalef went on to publish, as a single author or with colleagues of the IIP, three articles on the seasonal cycle of the phytoplankton of Blanes (covering samplings between 1945 and 1963), fifteen on the seasonal cycle (Fig. 1) off Castelló (1950-1964) and many others dealing with phytoplankton distribution and variability in places such as Vigo, Cádiz, Puerto Rico, Mauritania, Senegal and the Caribbean. After 1970, the phytoplankton papers published in Investigación Pesquera were mostly devoted to large-scale cruises in the NW African upwelling region, the Mediterranean and elsewhere. During the early fifties, phytoplankton was collected with net tows and temperature was measured only from surface waters, in many cases with the collaboration of the crews of a good number of fishing boats-an example of citizen science avant la lettre. Gradually, the number of observations and measurements increased, and analyses of phosphate (Margalef et al. 1957) and salinity were incorporated (Herrera and Margalef 1957). Margalef et al. (1954) introduced the quantification of pigments (as Harvey pigment units) using the method of Harvey and, in 1958 (Herrera and Margalef 1961) the availability of a spectrophotometer made it possible to determine pigments as $\mathrm{mg} \mathrm{m}^{-3}$ of

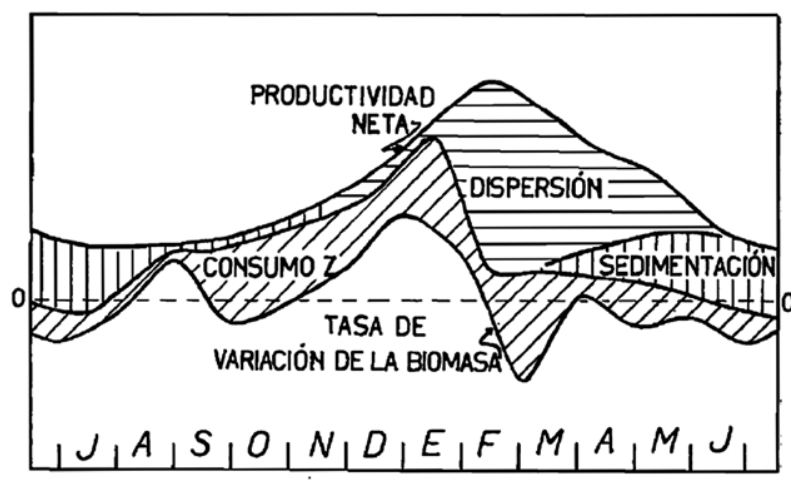

Fig. 1. - Theoretical and approximate interpretation of the seasonal cycle of phytoplankton in the waters of Castelló. Net primary production ("Productividad neta") has been derived from the assimilation/respiration ratio (made proportional to (chlorophyll/dry weight)*exp(9000/RT); consumption by zooplankton ("Consumo Z") has been considered to be proportional to the copepod density (data from Durán); the rate of variation of the biomass ("Tasa de variación de la biomasa") has been directly calculated from the observed monthly means; the sedimentation ("Sedimentación") is proportional to water stability; the dispersion ("Dispersión") has been estimated by difference (From Margalef et al. 1957: Fig. 7). 
chlorophyll. The quantification of phytoplankton by means of the inverted microscope technique was introduced in 1960 (Herrera and Margalef 1963). Starting in 1958 (Herrera and Margalef 1961), the Castelló sampling was carried out at three fixed stations that were visited with the Nika, a small boat of the Castelló laboratory, and Herrera and Margalef (1963) and Margalef and Herrera $(1963,1964)$ extended the observations over six to seven oceanographic stations located between Castelló and the Ebre River mouth. Margalef and Ballester (1967) and Margalef and Castellví (1967) studied the seasonal cycle of phytoplankton off Barcelona between 1965 and 1967 and also provided data on primary production measured with ${ }^{14} \mathrm{C}$, a technique recently introduced at the IIP (Herrera and Margalef 1966, Margalef and Herrera 1966).

In March 1970, at a time of strong international interest in upwelling systems, taking advantage of the presence in Barcelona of the vessels T.G. Thompson (USA) and Jean Charcot (France), the IIP and the International Biological Programme sponsored an international Working Conference on "Analysis of Upwelling Systems" that took place in Barcelona under the direction of Margalef. The main contributions to this meeting were published in volume 35(1) of Investigación Pesquera (1971). In the same year, the launch of the Cornide de Saavedra allowed research projects to be carried out in the upwelling region of NW Africa, then an important fishing area for Spain, which controlled the Spanish Sahara. Margalef was the chief scientist of the cruises Sahara II (1971) and Atlor II (1973). He wrote for Investigación Pesquera a witty account of the Sahara II cruise (Margalef 1971a) and a study of the phytoplankton distribution across the Catalan Front, based on data from three cruises of the García del Cid, in Investigación Pesquera (Margalef and Estrada 1987), but most results of these surveys were published in Resultados de las Expediciones Científicas or in international journals.

The naturalist studies of Margalef cited above contain qualitative and quantitative data on phytoplankton distribution, with extensive tables often accompanied by detailed descriptions and illustrations, but these contributions are much more than descriptive. Along with his examination of phytoplankton, Margalef strived to collect as many environmental data as possible. Based largely on the time series of Castelló and the Catalan coast, he described the main features of the seasonal cycle of coastal phytoplankton in the NW Mediterranean (Margalef and Castellví 1967). From time to time, he published revisions of the available information, with a view to finding regularities that could uncover ecological principles and guide further research (such as Margalef 1957e, 1961c, 1963c, 1965, 1969a,b). The quest to understand the environmental drivers of phytoplankton variability and their interactions with the ecophysiology of the various taxa (Fig. 2) led Margalef to build a conceptual model (Margalef 1978) in which the best predictor of dominant phytoplankton life-forms, defined as "the expression of adaptation syndromes of organisms to certain recurrent patterns of selective factors", was the available external energy, basically

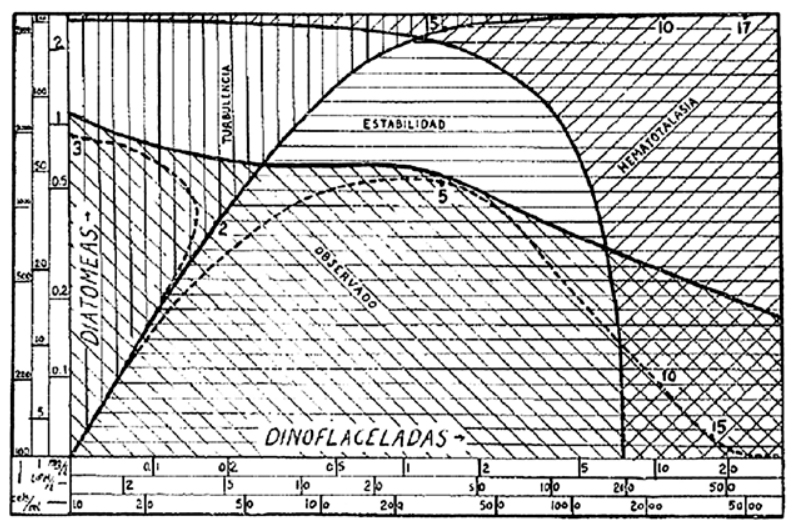

Fig. 2. - Diagram of the possibilities that can occur in a mixed population of diatoms ("Diatomeas", ordinate) and dinoflagellates ("Dinoflageladas", abscissa). The different stripes indicate states corresponding to stability ("Estabilidad"), turbulence ("Turbulencia"), red tide ("Hematotalasia") and actually observed situations ("Observado"). The combinations of stripes in relation to the composition of the mixed populations expresses the multiple possibilities that exist (From Margalef 1956e: Fig. 9).

manifested in the aquatic medium as water motion and turbulence. He proposed an ordination of dominant phytoplankton life-forms along an environmental gradient typical of seasonal phytoplankton succession in temperate regions, going from fertile and turbulent waters typical of a spring bloom period (dominated by diatoms) to nutrient-poor and stratified environments (dinoflagellates). This concept was summarized in a graph that became known as Margalef's mandala and inspired a great number of aquatic ecologists. The recognition of the basic role of external energy led Margalef to explore the interaction between small-scale turbulence and phytoplankton life-forms, a subject he addressed in his last publications in Scientia Marina (Margalef 1997a and Margalef 2001). A parallel research question, which attracted Margalef's attention early on, was that of the heterogeneity and patchiness of phytoplankton distribution, explored in Investigación Pesquera articles (Margalef 1956e, 1957c) and international contributions (Margalef 1958b), in which he uses observations from Castelló and the Ría de Vigo to develop the concept of phytoplankton succession, to highlight the importance of the physical environment (and the spatial heterogeneity) in the organization of plankton communities, and to discuss the potential of approaches based on information theory for assessing the diversity and spatio-temporal variability of phytoplankton. Margalef (1963c) compared peaks of species abundances to summits in a mountain range (Fig. 3) and tried to relate the structure of the phytoplankton distribution to the hydrographical background, while recognizing that factors such as water mixing and the persistence of populations would distort the result of local interactions. A later paper in Investigación Pesquera (Margalef and Estrada 1971) analysed the correspondence between phytoplankton patches and hydrographical structures by means of a computer program. For Margalef, the pelagic environment was a space structured by external energy that provided a variety of niches for different phytoplankton life-forms, a view 

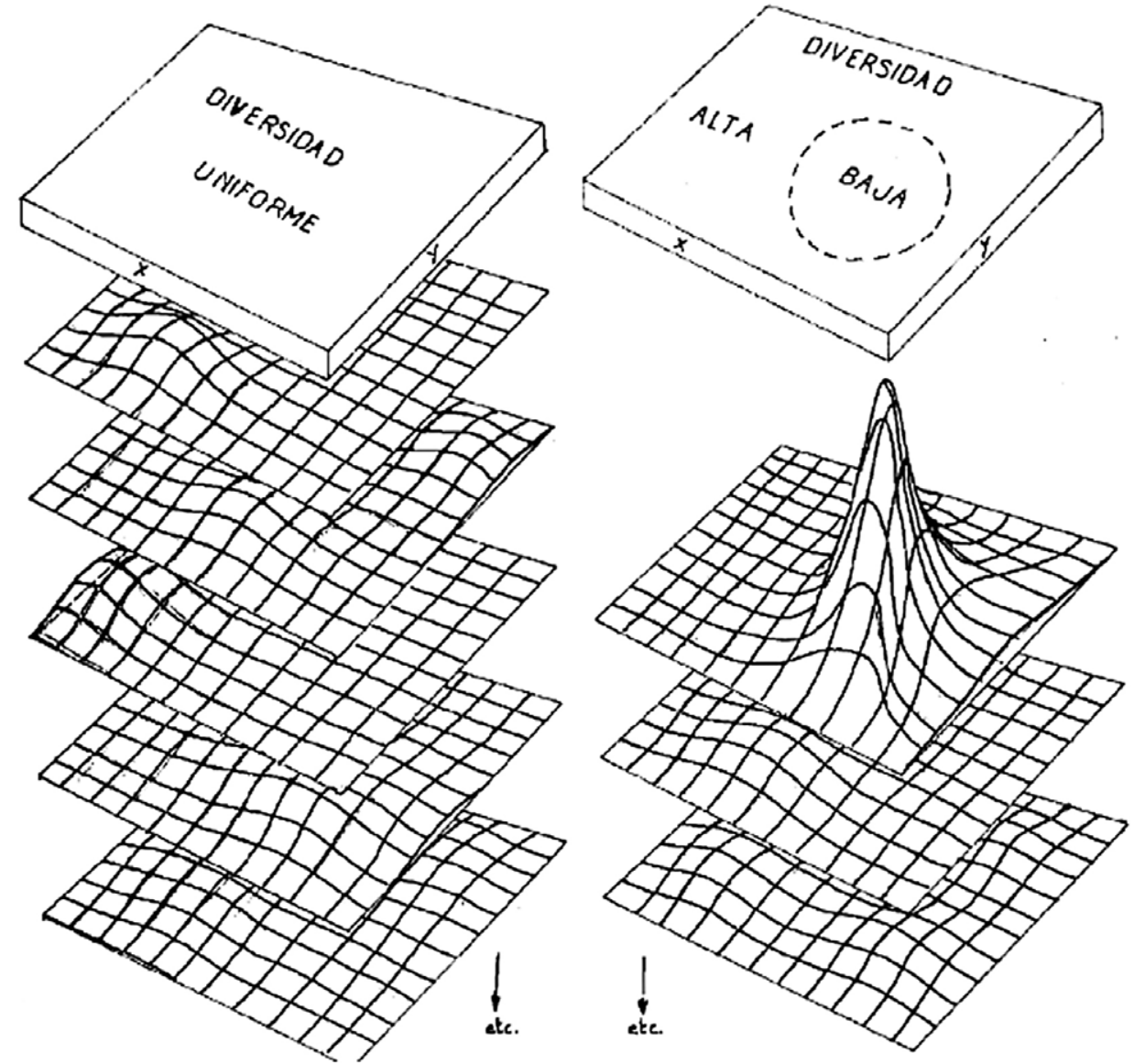

Fig. 3. - Conceptual representation of isotropic (left) and anisotropic (right) phytoplankton distributions. Diversity is uniform ("Diversidad uniforme") on the left and shows low diversity peaks in a high diversity background ("Diversidad, alta, baja") on the right. The coordinates $x$, $y, z$ may refer to a metric or to an ecological space (From Margalef 1963c: Fig 4).

that represented one of the explanations of the "paradox of the plankton" posed by Hutchinson (1961).

\section{RAMON MARGALEF AS A SCIENTIFIC ILLUSTRATOR}

Science has always included a strong component of visual effort. Especially for natural history, which is largely based on observation, illustration is the perfect tool for studying, understanding, describing and communicating the characteristics of the structure, environment and life cycle of animals and plants and for helping to understand new concepts and abstract ideas about the functioning of nature.

Coinciding with the increasing interest in natural history in the late 18th century, the collaboration of naturalists with expert artists brought added value to their studies (Dance 1990). Of course, naturalists with artistic skills had a supplementary advantage, adding to their scientific background the capacity to reproduce, with the fidelity required by the most rigorous taxonomist, details that even the use of mechanically reproduced images could often not provide (Alcaraz et al. 2015). Ramon Margalef was one of these scientists, a passionate observer of nature in whom a vast biological knowledge coincided with unusual drawing skills.
Margalef was attracted from his childhood by the beauty of life-forms. He observed, collected, and drew the little organisms that thrived in the pool at the small garden in the back of his house and in patches of abandoned fields. This early fascination with nature was documented in a number of notebooks full of drawings and annotations about insects and small aquatic animals and plants (Peters 2010), the prelude to his crucial role in the foundation of studies on aquatic ecology in Spain.

For more than a decade, from 1943 to 1955, Margalef's scientific publications were a miscellaneous representation of his interest in aquatic life in general. With the exception of a couple of studies on marine plankton, these publications formed part of a systematic and conscious approach to futhering knowledge of life in freshwater bodies. Most of the fundamentally descriptive papers on the morphology, habitat, life cycle and behaviour of a variety of aquatic organisms, from algae to insect larvae or crustaceans, are illustrated by wonderful original drawings. In his early papers dealing with freshwater fauna and flora (Fig. 4), the illustrations complementing the text were wonderful fine-line and stippling drawings reproducing species with minute morphologic details, artistically arranged in plates, some of them signed with his artistic cipher (Margalef 1943, 1944). 

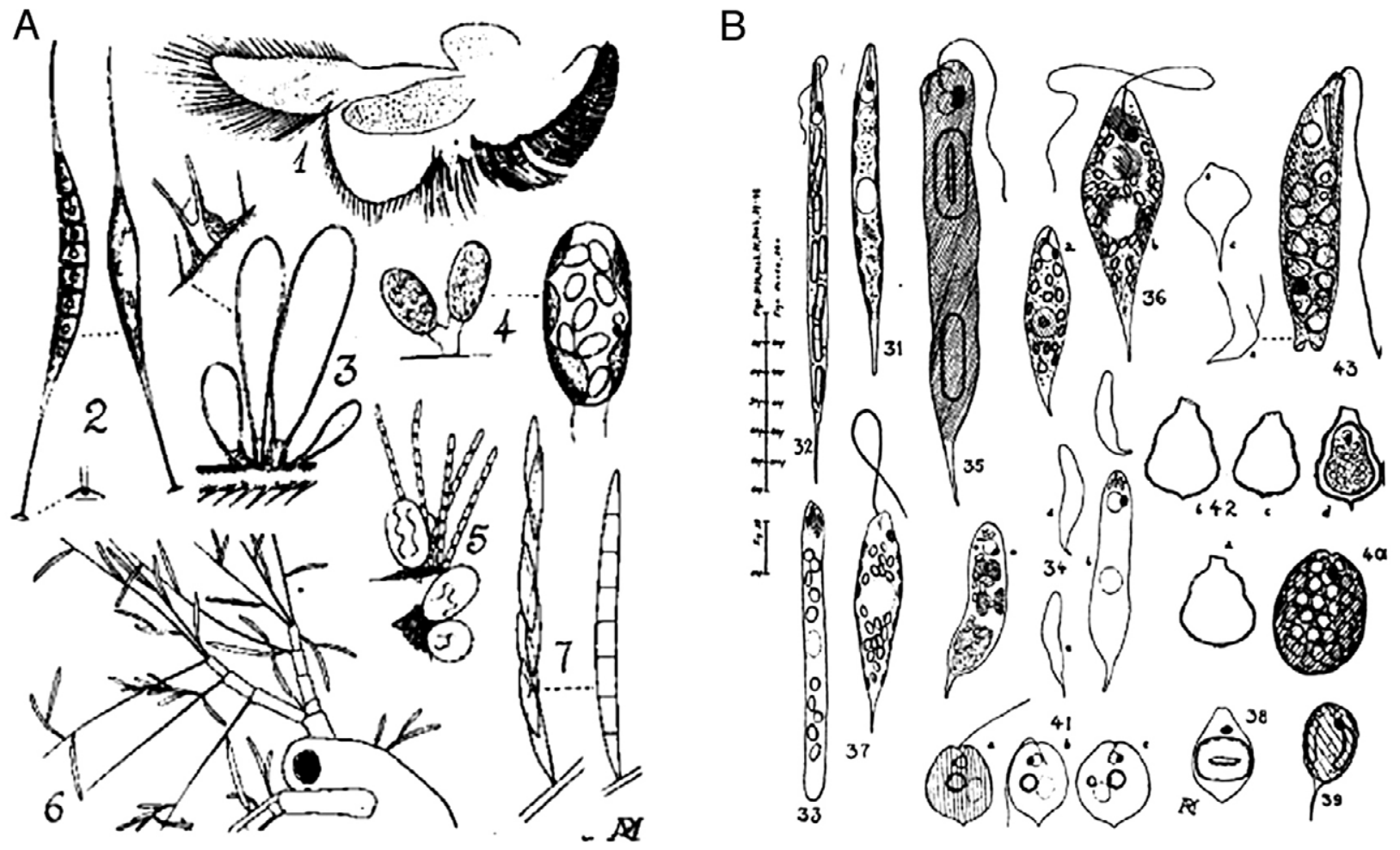

Fig. 4. - Some of the first published original illustrations of Ramon Margalef. Fine-line and stipple drawings. A) Epibionts on freshwater animals (Margalef 1943). B) Flagellatae (Margalef 1944).
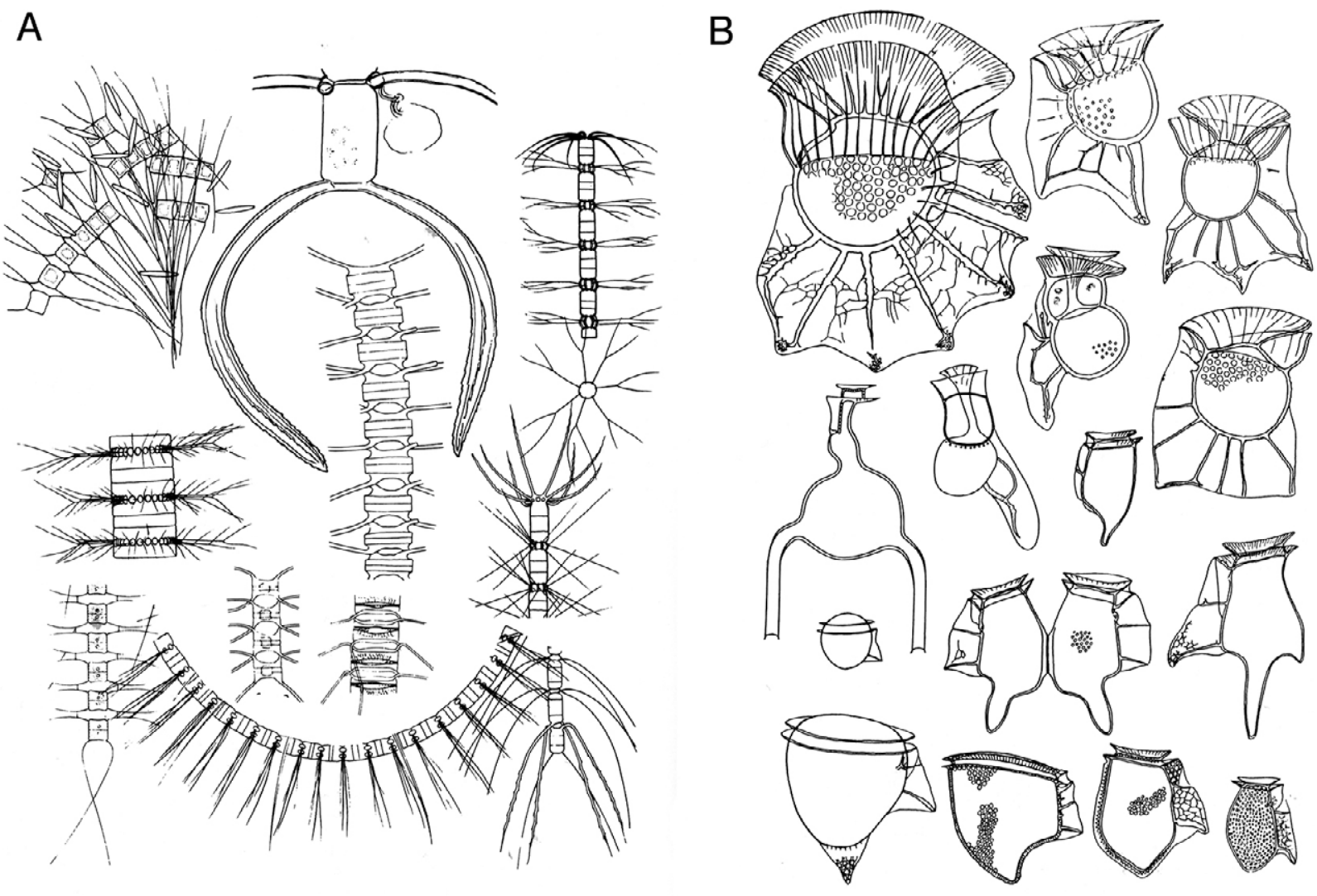

Fig. 5. - Original drawing from Ramon Margalef for Ecologia marina (Margalef 1967e, reproduced in Delgado and Fortuño 1991). Fine-line drawings. A) Diatoms. B) Dinoflagellates. 
When Margalef joined the IBA in 1945, his studies on marine plankton took on new energy, although he wrote few papers on this topic within his abundant and varied scientific production from 1945 to 1955 (Table 1). Two examples of his scientific rigour and technical and artistic ability stand out from this period: the introduction to the study of marine plankton (Massutti and Margalef 1950) and a monograph on Iberian freshwater crustaceans (Margalef 1953c), both with excellent original illustrations that are still being used as valuable taxonomic guides.

When Investigación Pesquera was launched, most of Margalef's scientific papers concerning marine life were published in this or in sister journals (although there are also unpublished excerpts from Reuniones sobre Productividad y Pesquerías, mimeo records of communications mainly on technological aspects), while his limnological studies were still being published in Publicaciones del Instituto de Biología Aplicada.

Around half of the publications of Ramon Margalef on marine plankton either in Publicaciones del Instituto de Biología Aplicada or Investigación Pesquera consist of studies about the community composition, spatial distribution, temporal succession and production of phytoplankton in coastal localities of the Mediterranean or the Atlantic. These publications, besides being an exhaustive inventory of species and environmental data, include original illustrations of particular species, fine-line drawings of great taxonomic fidelity that are arranged in plates of unusual aesthetic taste (Fig. 5).
Aside from the naturalistic traits, Margalef's new ideas required texts and verbal descriptions to be complemented with illustrations capable of going beyond the limits of language. Graphs, charts and diagrams were used to facilitate the communication of abstract concepts by means of formal similitudes aiming to concentrate huge amounts of information into a form in which it would be more easily absorbed by the reader (Tufte 1983). As the early papers published by Margalef in Investigación Pesquera were devoted to the description of seasonal cycles of phytoplankton, the interaction regularities observed between environmental variables and quantitative plankton data had to be synthesized in charts and infographic solutions that helped explain novel concepts and theories, defined as Margalef's “drawn ideas" (Segarra 2019).

The use of infographics covers many of Margalef's studies, ranging from the relations between temperature and morphological and physiological characters such as size, metabolic activity and water content in phytoplankton cells (Margalef 1953b) to the composition of autotrophic pigments in phytoplankton and other organisms in relation to community structure (Margalef 1964b). His models on the formation of plankton patches, including the particular case of noxious phytoplankton blooms (spatial distribution, abundance and even demographic composition) as a function of diffusion rate, motility, reproduction and mortality (Fig. 6), were among the first contributions in which the use of infographics helped the understanding of complex physical and biological interactions (Margalef 1956e, 1957c).

A
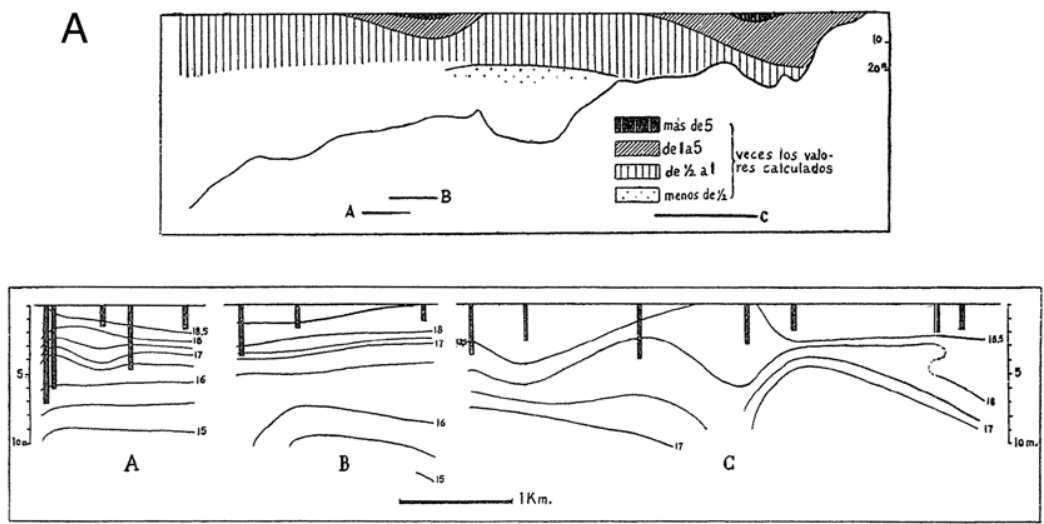

B

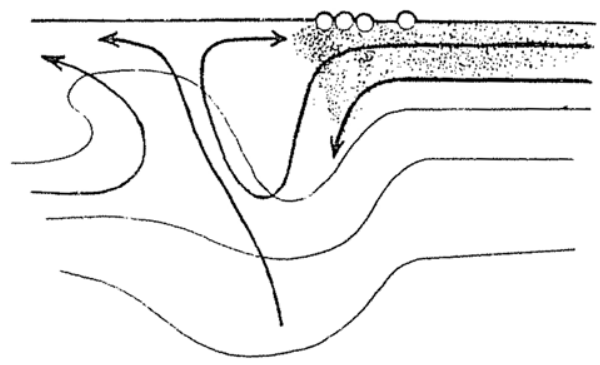

Fig. 6. - A: Spatial cell concentration during a red tide along the longitudinal axis of the Ria of Vigo. B: The origin of the sharp borders in a red tide patch, and the formation of foam as a consequence of a horizontal swirl (Margalef 1956e). 


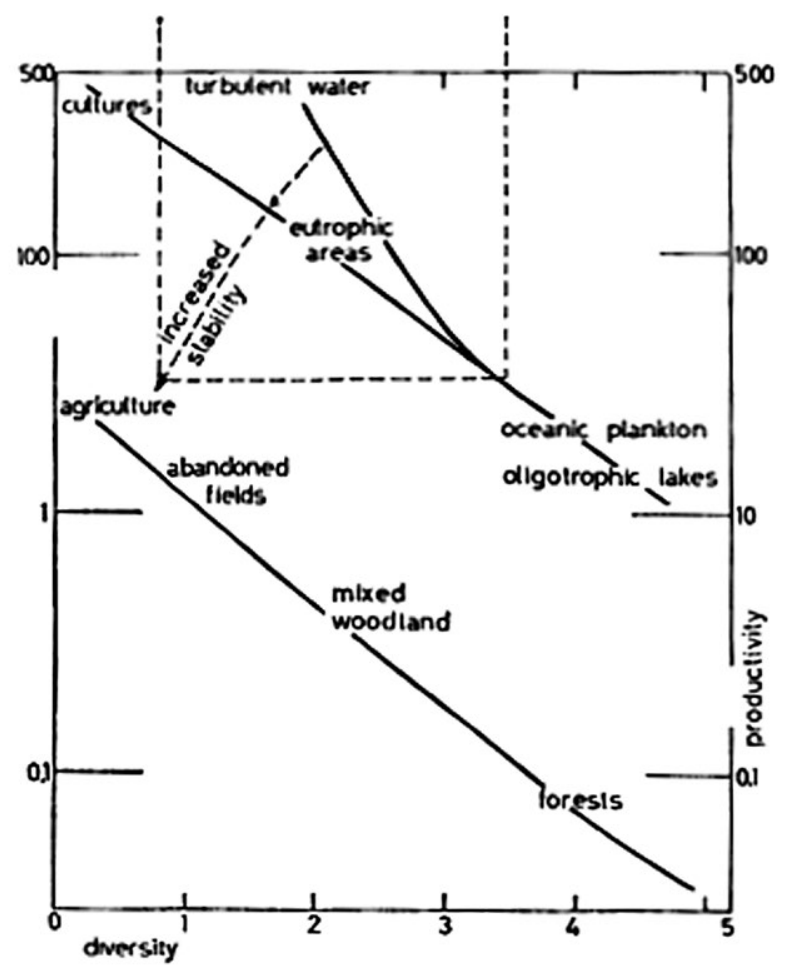

Fig. 7. - Schematic representation of the quotient productivity/biomass in relation to diversity corresponding to Mediterranean phytoplankton (square limited by the dashed lines). The whole graph corresponds to data for different ecosystems as described in Margalef (1969c). (Margalef 1970b).

The new style of graphic representations also helped to explain the complex, multidimensional relations between hydrography and fisheries (Margalef and Andreu 1958), to describe the patterns in the spatiotemporal variability of phytoplankton groups as defined by their life-style (phytoplankton life-forms) according to the effects of a number of variables, and to express the relation between structural properties and function (Fig. 7) (Herrera and Margalef 1957, Margalef 1957e, 1961b, 1963c, 1970b, Margalef et al. 1959, Margalef and Herrera 1963). Probably the most widespread and best known of Margalef's "drawn ideas" is the simple graphic presentation of the temporal succession of phytoplankton life-forms as selected by the possible combinations of mechanical energy (turbulence) and nutrients, universally known as Margalef's mandala (Margalef 1978).

\section{PHYSICAL MODELS: "RAIN-MAKING" MACHINES AND OTHER INVENTIONS; ECOPHYSIOLOGY}

Those who worked closely with Margalef would have seen and frequently used (and sometimes suffered) apparatus that could not be precisely classified as standard oceanographic equipment. His students had a term to define these inventions: Margalef's "rainmaking machines". In Spain, a broken country after the civil war, sampling, measuring and experimental devices and scientific equipment in general were simply non-existent or impossible to acquire. Therefore,

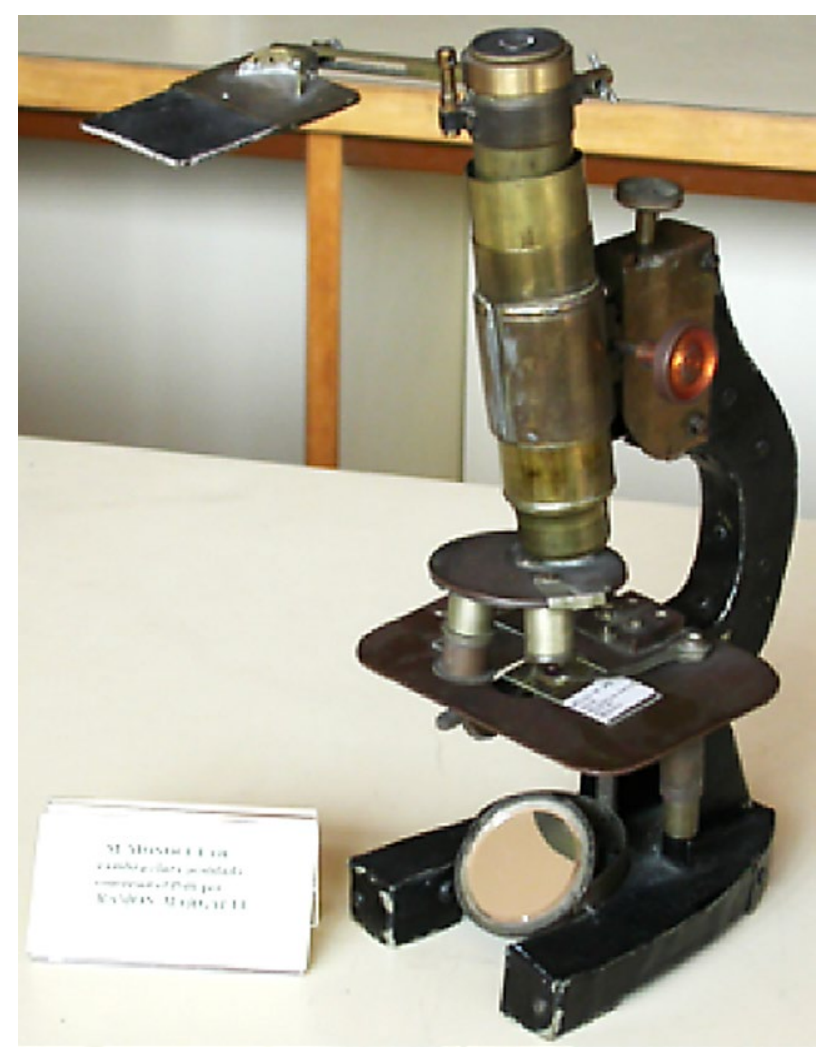

Fig. 8. - Margalef's home-made microscope. The optics were acquired in the Barcelona flea markets and the stand with the focusing system and the camera lucida was built by Margalef. (Photograph: Margalef family archive).

Margalef conceived, designed and sometimes built himself the required equipment, as happened with his first microscope, made by joining optical pieces found in flea markets to a self-made mechanical stand, with a camera lucida he also made and adapted to it (Fig. 8). Other miscellaneous inventions include laboratory columns with electrodes to study the suspension of phytoplankton according to changes in their physiological state, such as those produced by photosynthetic activity that could modify their surface electric charges (Margalef 1957b), an idea that was further developed into a device for measuring depth differences in electric potential in the marine water column, as a proxy for vertical water movements, phytoplankton abundance and vertical migration, or photosynthetic state (Margalef 1967b). Most of the prototypes of new apparatus were made with Meccano, a first class kit with all types of gears, sprockets, drive chains and even an electric motor. At sea, Margalef made small repairs with a multi-purpose Swiss pocket knife. Unfortunately, probably due to the provisional nature of some of his designs, as well as the general laziness and lack of interest in preserving our history, only a couple of Ramon Margalef's devices have survived today.

Improving the representativeness of plankton samples was a constant motto for Ramon Margalef since his first studies on marine plankton (Margalef et al. 1952, 1954). The evaluation of phytoplankton biomass, first using as an estimator Harvey's colour pattern (Harvey units) and later through spectrophotometric analysis of 

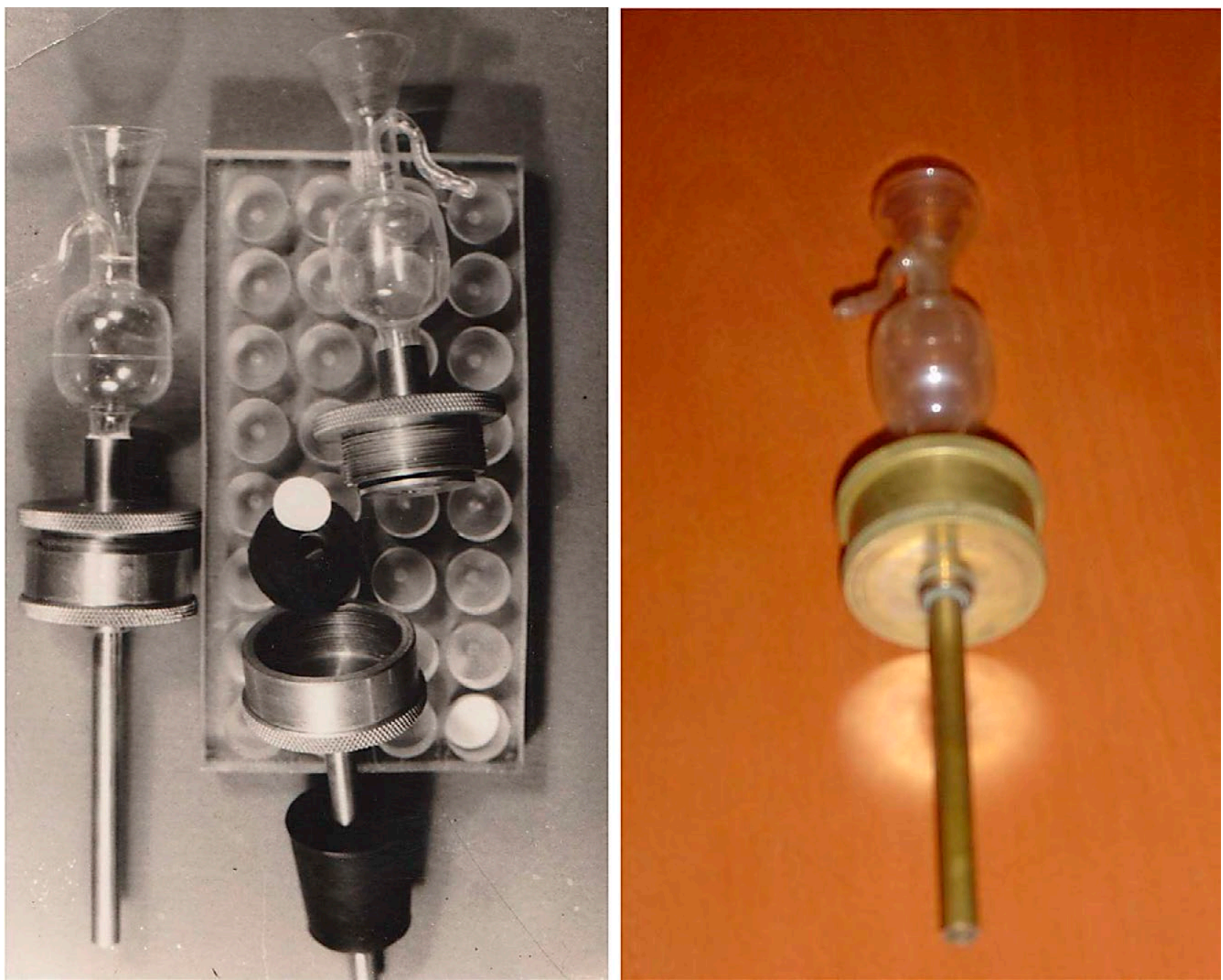

Fig. 9. - Seawater filtration equipment, one of the few remaining devices designed by Margalef. The glass part is an automatic volumedispenser system (Margalef 1954c). (Photography: M. Alcaraz).

chlorophyll concentration, required robust, efficient and easy-to-use water filtering devices. The designs included systems for filtering a known water volume (originally through home-made collodion filters, as mentioned in the Reuniones de Productividad y Pesquerías) and semi-automatic machines for multiple data collection (Figs 9, 10 and 11; Margalef et al. 1952, Margalef 1954 a,b)

After a trial to carry out simultaneous spatial surveys of phytoplankton and physico-chemical variables at series of stations carried out off the coast of Castelló (Margalef and Herrera 1964), the next steps consisted in the design of really complex, semi-automatic multiparameter samplers (the real "rain-making machines"). These were aimed at obtaining simultaneous estimations of environmental variables and phytoplankton and zooplankton data, in order to study the ecological principles responsible for the spatio-temporal patterns observed in phytoplankton biomass and distribution, patch formation and production. The idea was to replace the rigid, time-consuming protocol of classic oceanographic cruises, in which samples were taken at standard depths at fixed stations regularly distributed in transects or grids, with continuous measurements

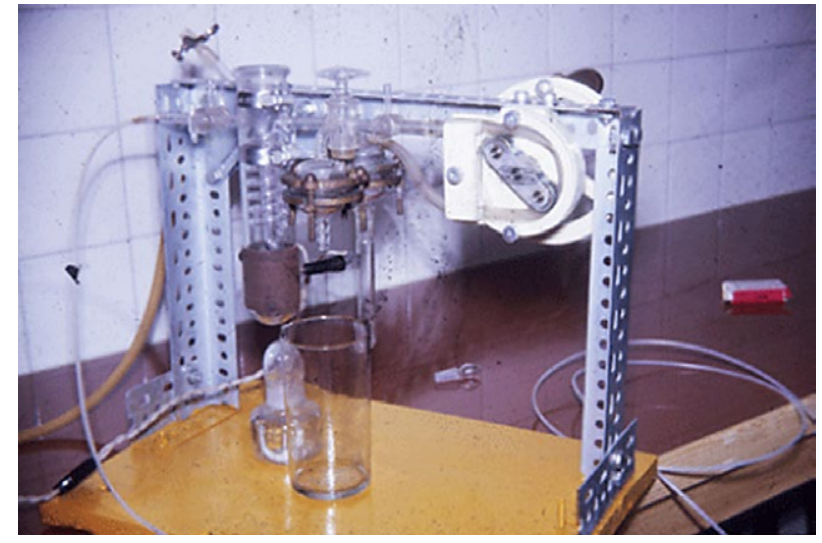

Fig. 10. - One of the devices for the automatic extraction of phytoplankton pigments (Margalef 1961f). (Photograph: ICM archive).

of multiple variables along the ship's track as it was in motion. This allowed a quasi-synoptic view of the hydrographic structure and its relation to the heterogeneity of plankton distribution to be obtained.

In an initial stage, Margalef (1967d) used optical particle counters to measure seston concentration from sub-surface water samples coming from a continuous 

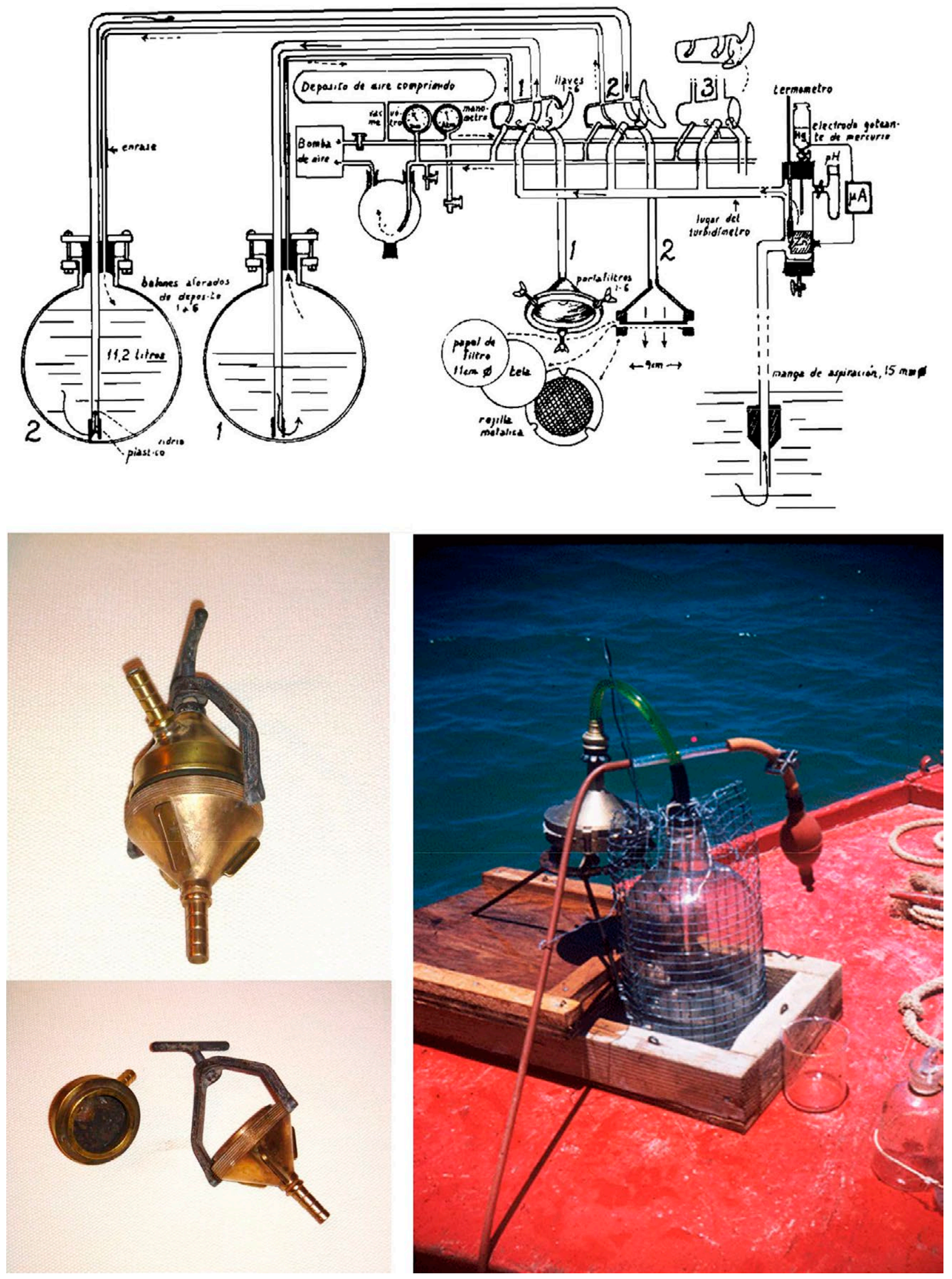

Fig. 11. - Schematic representation of the seawater filtering system installed on board the R/V Nika of the IIP Castelló. In the photographs, the only remaining pieces of the system. (Photograph: M. Alcaraz and ICM archive). 


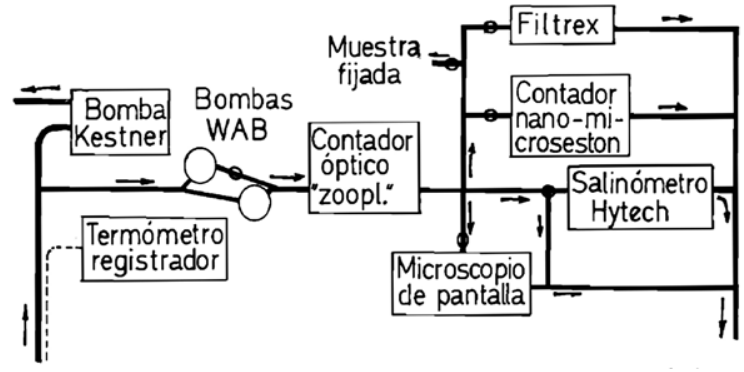

Fig. 12. - Schematic representation of the system for obtaining continuous, quasi-simultaneous data on marine physical, chemical and biological variables. It was used in the Belgian "Mediterranean

Outflow" cruise on board the Mechelen. (Margalef 1967d).

water flow with the ship in motion (Fig. 12). Later, starting with the Sahara II cruise on board the Cornide de Saavedra, the equipment for the continuous in situ survey included combinations of continuous automatic measurements of physical parameters (temperature) and chemical parameters (salinity, inorganic nutrients), in a setup that had been implemented by Antoni Ballester (Ballester et al. 1973), with semi-continuous estimates of plankton variables such as photosynthetic pigments, abundance and size-spectrum of suspended particles, water samples for taxonomic phytoplankton analysis, zooplankton abundance (optical plankton counters) and fish biomass (Margalef 1971a). The sampling protocol, which required keeping watches in the long tracks between oceanographic stations, consisted in taking water samples every 15 minutes, reading the sensors, annotating the data that could not be recorded

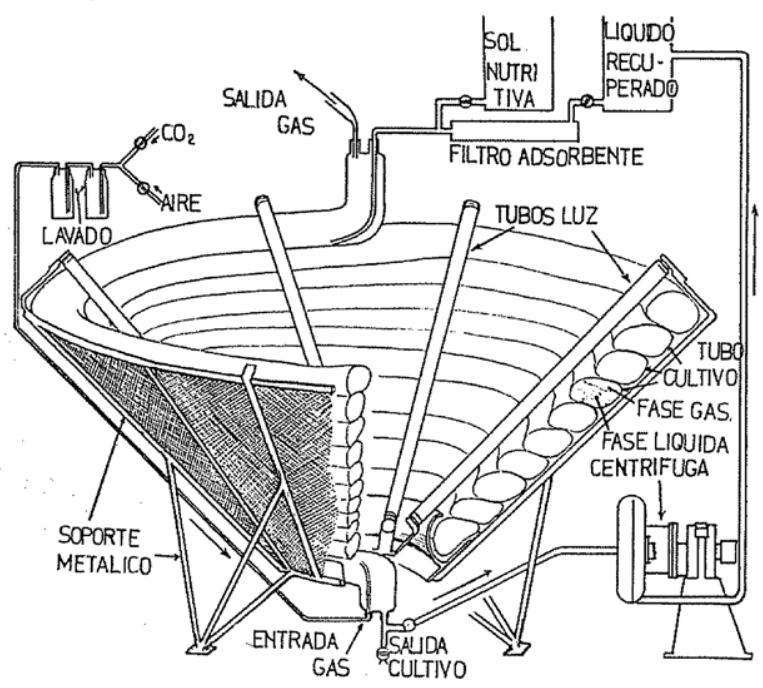

Fig. 13. - The "Helicotrefon", one of the physical models used by Margalef in the study of plankton succession. The system consisted of a transparent helicoidal plastic tube supported by an inverted conical frame. Nutrients and inoculum were introduced in the upper part. The continuous nutrient flow was regulated according to the duplication rate of the species so that the maximum algal concentration occurred in the lower end, where algae were separated and concentrated with a continuous centrifuge. The liquid, once the consumed nutrients had been amended, was incorporated again at the upper end. It could be an interesting prototype for mass production of microalgae. (Margalef 1956a).

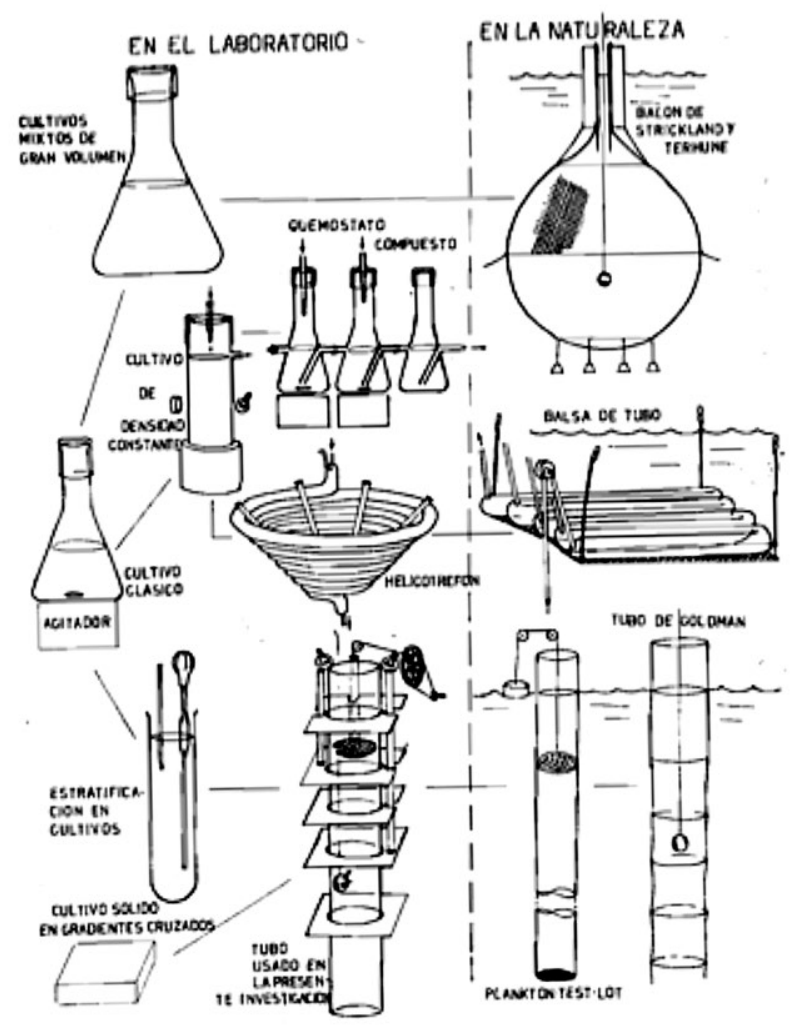

Fig. 14. - Laboratory and field devices used and discussed by Ramon Margalef as physical models of marine ecosystems. (Margalef 1963b).

on magnetic or paper tape, controlling the functioning of chemical autoanalysers and other activities, was the subject of jokes among the students who carried it out.

Some of Margalef's theories required the design of experimental devices contrived to test the effects of particular factors (e.g. temperature, nutrients and turbulence) as drivers of the function and ecophysiology of phytoplankton. The usefulness of laboratory analogues of planktonic ecosystems was thoroughly discussed in Margalef (1956a, 1963b); the devices ranged from the simple culture vessels to compound chemostats, which consisted of serially-connected culture flasks, so that different phytoplankton species would predominate in different flasks according to the division rate of the species and the nutrient flow determining their loss by dilution. Especially noteworthy was the design of the "Helicotrefon", a phytoplankton culture system consisting of a transparent helical tube installed in a funnel-shaped frame. Nutrients and the phytoplankton inoculum were added at the upper end at a rate calculated to have the maximum phytoplankton concentration at the lower end, where a continuous centrifuge separated cells from the culture medium, which was reused after its nutrient composition had been rectified (Figs 13, 14).

Margalef was also interested in ecophysiological questions that required either mixed or unispecific phytoplankton populations to be maintained under controlled environmental conditions. For his $\mathrm{PhD}$ thesis, which aimed to study the effects of temperature on the shape and size of phytoplankton (Margalef 1953a), he 


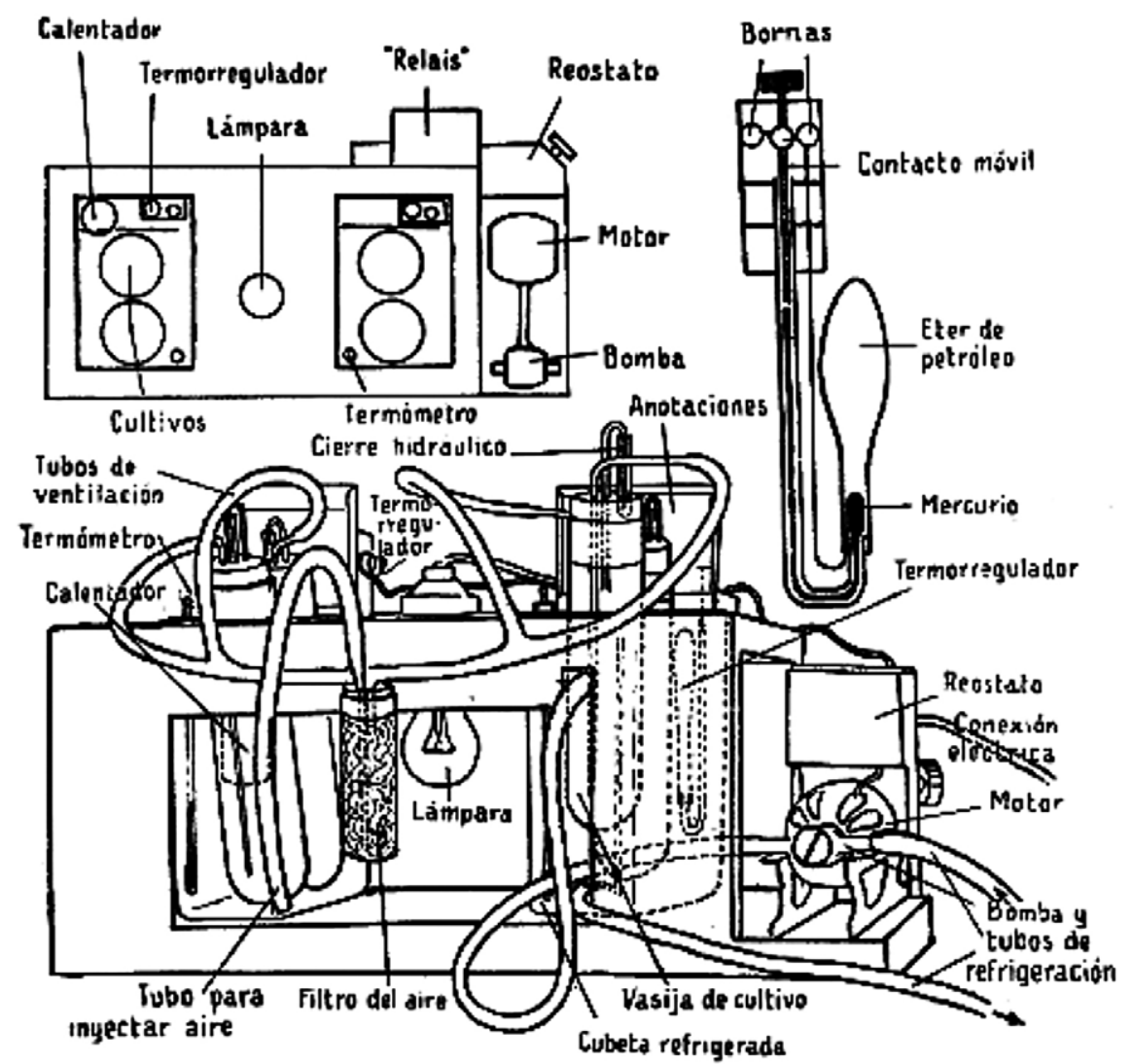

Fig. 15. - Diagram of the phytoplankton culture system used to study the effect of temperature of the size and shape of microalgae by Margalef for his PhD thesis. Temperature, light and nutrients were automatically controlled. (Margalef 1953a).
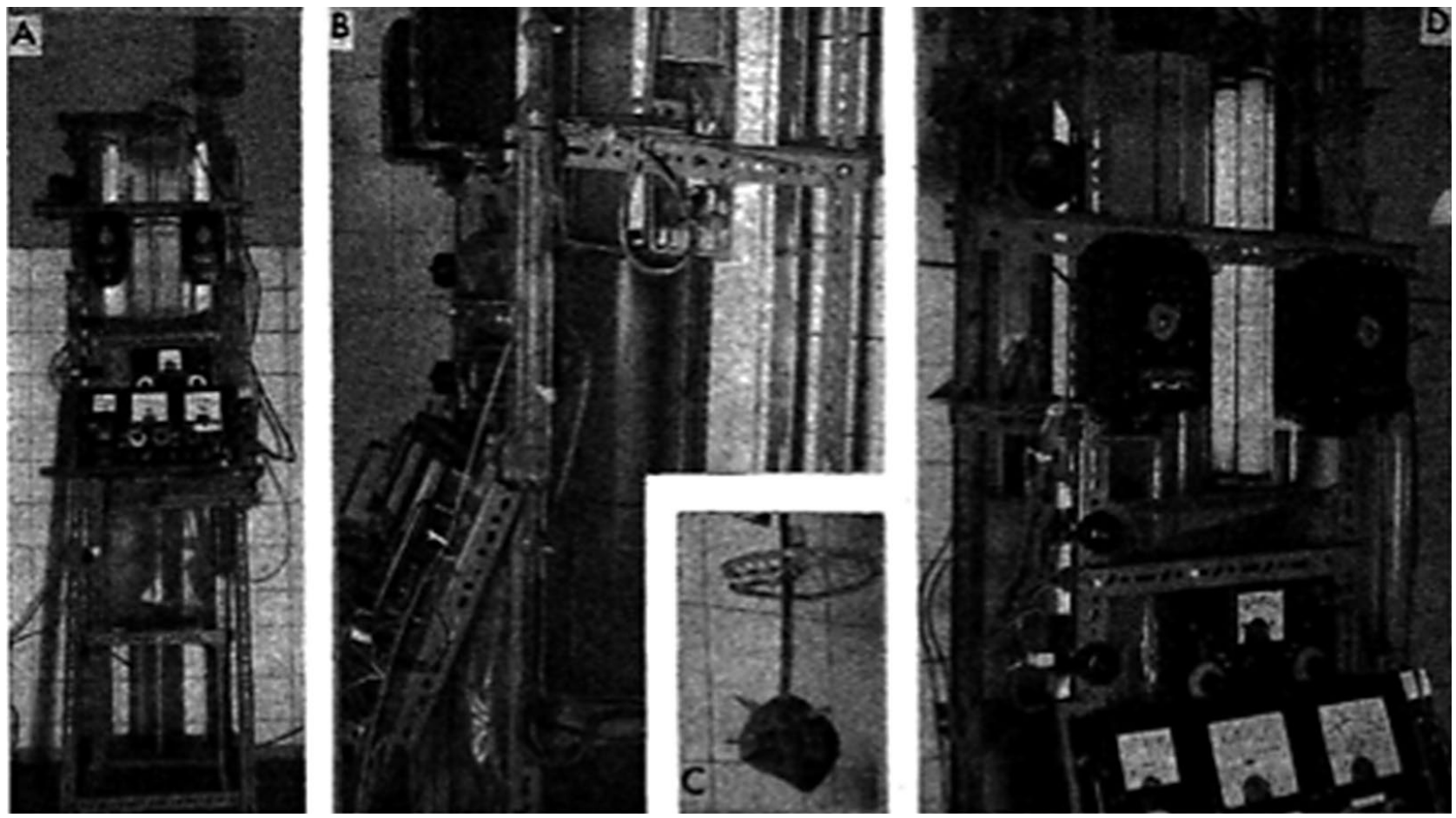

Fig. 16. - Details of the physical analogues of the marine water column (laboratory microcosms) for the study of the ecophysiology, pigment composition and depth distribution characteristics of phytoplankton in relation to the vertical profiles of temperature gradients (thermocline), light intensity, nutrients and turbulence. The culture conditions could be automatically controlled. More details in Margalef (1963b). 
designed a system (Fig. 15) in which light, temperature and nutrients could be controlled (Margalef 1954b).

The vertical light gradient and density structure (thermocline) of the oceanic water column was simulated by Margalef in the laboratory using $30 \mathrm{~L}$ transparent Perspex cylinders (Fig. 16); in these microcosms, temperature, light and vertical water movement (produced by an oscillating grid attached to a motor) could be automatically controlled, and a small probe allowed fine-scale water sampling for measurements of physical, chemical and biological variables (Margalef 1963a, b). Decades later, this methodology was the inspiration for a fruitful research line at the ICM in relation to the effect of small-scale turbulence on plankton ecosystems (Margalef 1997a, Estrada et al. 1987, Alcaraz et al. 1988, Marrasé et al. 1990, Saiz et al. 1992, Peters et al. 2002, Berdalet et al. 2011).

\section{THEORETICAL ECOLOGY: DIVERSITY, DISTRIBUTIONS AND MATHEMATICAL APPLICATIONS}

Margalef's fascination with nature and his detailed phytoplankton observations were the basis for his contributions to theoretical ecology, and many of his early articles already contain the seed of ideas and concepts that he continued to develop later on. From the beginning, Margalef's dedication to the examination of phytoplankton was accompanied by an interest in finding regularities and establishing unifying principles. Very soon, he realized the importance of patterns in the number and distribution of species, a field that he had initially developed in relationship with terrestrial communities. Margalef (1949) presented a critique of existing indexes of diversity, which were generally based on adjusting the distribution of the number of individuals of each species to particular mathematical functions. Margalef wanted to find a quantitative expression of diversity that would not depend on previous mathematical assumptions and, in Margalef (1956b), he pointed out the relationship between the richness or specific diversity of a community and the information provided by a sample of this community, and proposed a diversity index based on an expression devised by Brillouin (1951) to define the entropy of a message. This research line matured one year later with Margalef's opening speech for the Royal Academy of Sciences and Arts of Barcelona, on "Information theory in ecology", which was published in the reports of the Academy (Margalef 1957f). In this work, Margalef proposed to express diversity by means of an index $(\mathrm{H})$ derived by Shannon and Weaver (1949) to measure the information of a set of symbols (phytoplankton species when applied to plankton) with different a priori probabilities (different frequencies in the case of species). Using some approximations, $\mathrm{H}$ and the Brillouin index could be demonstrated to be equivalent, but $\mathrm{H}$ was easier to calculate and was more suitable for estimating the diversity of random samples extracted from a community. Though it was published in Spanish and in a country that at that time was not particularly appreciated for its scientific output, "Information theory in ecology" soon attracted international attention, as shown by the appearance of an English translation in the following year (Margalef 1958b). Since then, there have been numerous applications of information theory in ecology and the topic continues to be important today.

The concept of diversity could be applied not only to species numbers but also to traits such as size and biochemical composition. This was the subject of a publication in Scientia Marina (Margalef 1994) based on a contribution to the "NATO Experimental Workshop on the Size Structure and Metabolism of the Marine Microbial Food Web" held in Málaga in 1993. Margalef viewed diversity as a dynamic property, so relationships with other ecosystem characteristics had to be sought in terms of derivatives rather than by considering point values of the variables. For example, biomass would not be directly correlated with diversity, but an acceleration in the production of biomass after a nutrient addition would be associated with a decrease in the first derivative of diversity with respect to time. Margalef also recognized that the idea of species distributions as carriers of information could be applied to spatio-temporal relationships. In this context, he proposed the use of "diversity spectra", which related species richness or the value of diversity indices to the size or volume of the samples, as ecological descriptors. Reference to the need to consider spatial scales when examining diversity was a constant in Margalef's publications dealing with this topic (Margalef 1970b, 1972c, 1994).

Margalef's quest to develop a theoretical framework for ecology was accompanied by an interest in quantitative methods that could help to describe and interpret natural entities, from organisms to ecosystems. He pointed out the insufficiency of routine calculations used at the time in fisheries and oceanography (Margalef 1970a) and searched for new applications of mathematical models and tools, statistical and otherwise. Within this framework, Margalef organized the Seminar of Mathematical Ecology and the Seminar on Factor Analysis in Ecology and Taxonomy, the contributions and discussions of which were published in volumes 34 (1970) and 36 (1972) of Investigación Pesquera. Among the subjects that were discussed in these seminars was network theory (Alvarado and Bonet 1970), currently at the forefront of theoretical ecology developments. Margalef was also interested in mathematical models and one of his early publications in Investigación Pesquera (Margalef 1957c), inspired by research on fisheries, dealt with mathematical functions describing the dispersion of organisms with one or more age classes around a centre (e. g. a breeding centre). Later on, Margalef (1973) pointed out weaknesses of the models of the time, such as the lack of consideration of space, and formulated some principles for the hierarchic construction of models. Margalef (1979), one of his last publications in Investigación Pesquera, used the classical formulation of population changes by means of differential equations to highlight that the condition for population regulation was that inputs (e.g. births and immigration) and outputs (e.g. 


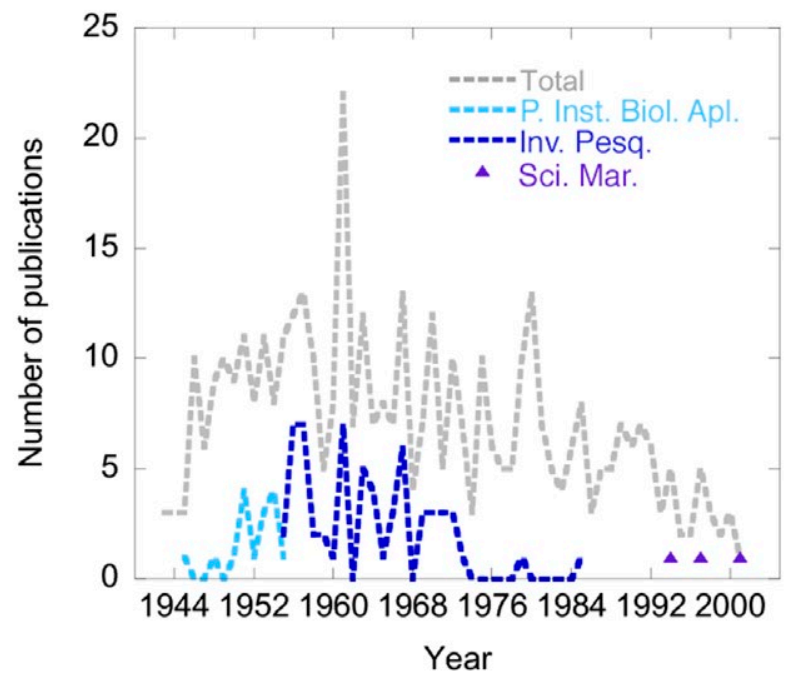

Fig. 17. - Publications of Ramon Margalef between 1945 and 2001. Total number and articles in Publicaciones del Instituto de Biología Aplicada, Investigación Pesquera and Scientia Marina per year.

death and emigration) should be nonlinear functions of the number of individuals, with a higher exponent for outputs.

\section{CONCLUDING REMARKS}

Margalef's contribution to Investigación Pesquera, a total of 62 articles, was crucial to shaping the editorial line of this journal and became a pillar of its international recognition (Peters 2010). Scientia Marina, the successor to Investigación Pesquera, was included in the Science Citation Index in the late 1990s and, at present, its impact factor is 1.252 (2018); the journal is completely open access, publishes about 40-50 articles per year and is one of the few that is still managed directly by a scientific institution.

Given the international appreciation achieved by Margalef, a question that has merited comments by his biographers (Peters 2010) is why he wrote so much of his work in Spanish and did not seek to publish in more renowned journals. We must remember that the scientific communication system of the time was different from the present one. It was usual (or even expected) for scientists to publish in the journal of their own institution and, although some journals were more prestigious than others, ranking metrics were not in use. Investigación Pesquera was exchanged with the journals of numerous institutions around the world and the most common way of obtaining an article that was not available in the library was to write to the author requesting a reprint. As suggested by Peters (2010), it is likely that Margalef felt that the language would not be a barrier for interested colleagues. In addition, he surely valued the ability to publish extensive tables of data and to roam into interdisciplinary considerations without editorial constraints. This feeling surfaces in Margalef's preface to Our Biosphere, a book written on occasion of the 1995 prize of the International Ecology Institute (ECI): "The requirement for laureates to write an EE book provides a welcome opportunity to express oneself more freely than is possible under ordinary publication procedures".

Reading Margalef's works through the volumes of Publicaciones del Instituto de Biología Aplicada, Investigación Pesquera and Scientia Marina (Fig. 17) represents a journey through the foundations of marine ecology, first in coastal waters of the Iberian Peninsula and later in some crucial places of the global ocean such as the Caribbean and the upwelling region of NW Africa. In addition to his descriptions of phytoplankton and other marine organisms, a review of the publications of Margalef in these journals allows us to trace how he developed many of his scientific ideas and established a number of unifying principles that continue to inspire current ecological research. The journal Investigación Pesquera, together with its predecessor, Publicaciones del Instituto de Biología Aplicada, and its successor, Scientia Marina, thus constitute the guardians of a fundamental heritage for all marine scientists.

\section{ACKNOWLEDGEMENTS}

We thank Franz Peters for data on the total number of publications of Ramon Margalef and Maria Victòria Martínez de Albéniz for information on Scientia Marina.

\section{REFERENCES}

Alcaraz M., Saiz E., Marrasé C., et al. 1988. Effects of turbulence on the development of zooplankton biomass and copepod populations in marine microcosmos. Mar. Ecol. Progr. Ser. 49: 117-125. https://doi.org/10.3354/meps049117

Alcaraz M., Correia F., Cerviño C. 2015. Scientific illustration. An indispensable tool for knowledge transmission. CONFIA, 2nd Int. Conf. On illustration and animation, Braga (Portugal), pp. 261-278.

Alvarado R., Bonet E. 1970. Réseaux. Inv. Pesq. 34: 73-82.

Ballester A., Cruzado A., Julià A., et al. 1973. Análisis automático y continuo de las características físicas, químicas y biológicas del agua de mar. Alimentaria: Rev. Tecnol. Hig. Aliment. 47: 91-93.

Berdalet E., Llaveria G., Simó R. 2011. Modulation of small-scale turbulence on methylsulfoniopropionate (DMSP) concentration in an Alexandrium minutum (Dinophyceae) culture: link with toxin production. Harmful Algae 11: 88-95. https://doi.org/10.1016/j.hal.2011.08.003

Bonnín P. 1994. Ramon Margalef. Fundació Catalana per a la Recerca, Barcelona, $183 \mathrm{pp}$.

Brillouin L. 1951. Physical Entropy and Information. II. J. Appl. Phys. 22: 338. https://doi.org/10.1063/1.1699952

Dance S.P. 1990. The art of Natural History. Arch Cape Press, N.Y. $224 \mathrm{pp}$.

Delgado M., Fortuño J.M. 1991. Atlas de fitoplancton del Mar Mediterráneo, Sci. Mar. 55 (Suppl. 1): 1-133.

Durán M., Saiz F., López-Benito M., et al. 1956. El fitoplancton de la ría de Vigo, de abril de 1954 a junio de 1955 . Inv. Pesq. 4: 67-96.

Durfort M. (ed.). 2005. Ramon Margalef. Institut d'Estudis Catalans i Reial Acadèmia de Ciències i Arts de Barcelona, Barcelona, $92 \mathrm{pp}$.

Establier R., Margalef R. 1964. Fitoplancton e hidrografía de las costas de Cádiz (Barbate), de Junio de 1961 a Agosto de 1962. Inv. Pesq. 25: 5-31

Estrada M., Alcaraz M., Marrasé C. 1987. Effects of turbulence on the composition of phytoplankton assemblages in marine microcosmos. Mar. Ecol. Progr. Ser. 36: 267-281. https://doi.org/10.3354/meps038267 
Herrera J., Margalef R. 1957. Hidrografía y fitoplancton de las costas de Castellón, de Julio de 1956 a Junio de 1957. Inv. Pesq. 10: $17-44$.

Herrera J., Margalef R. 1961. Hidrografía y fitoplancton de las costas de Castellón, de Julio de 1958 a Junio de 1959. Inv. Pesq. 20: $17-63$.

Herrera J., Margalef R. 1963. Hidrografía y fitoplancton de la costa comprendida entre Castellón y la desembocadura del Ebro, de Julio de 1960 a Junio de 1961. Inv. Pesq. 24: 33-112.

Herrera J., Margalef R. 1966. Estimación de la actividad total añadida y de la autoabsorción en las determinaciones de producción del fitoplancton con ${ }^{14} \mathrm{C}$. Inv. Pesq. 30: 37-44.

Herrera J., Muñoz F., Margalef R. 1955. Fitoplancton de las costas de Castellón durante el año 1953. Inv. Pesq. 1: 17-29.

Hutchinson G. E. 1961. The paradox of the plankton. Am. Nat. 95: 137-145. https://doi.org/10.1086/282171

Lleonart J., Olivar M.P. 2011. The history of Scientia Marina. Contrib. Sci. 7: 175-183. https://doi.org/10.2436/20.7010.01.124

Margalef R. 1943. Los epibiontes en los animales de agua dulce. Euclides 3: 609-613.

Margalef R. 1944. Datos para la flora algológica de nuestras aguas dulces. Publ. Inst. Bot. Barcelona 4: 1-130.

Margalef R. 1945-1946. Fitoplancton nerítico estival de Cadaqués (Mediterráneo catalán). Publ. Inst. Biol. Apl. 2: 8995.

Margalef R. 1948-1949. Fitoplancton nerítico de la Costa Brava en 1947-48. Publ. Inst. Biol. Apl. 5: 41-51.

Margalef R. 1949. Una aplicación de las series logarítmicas a la fitosociología. P. Inst. Biol. Apl. 6: 59-72

Margalef R. 1950. Plancton recogido por los laboratorios costeros, I. Plancton de Blanes durante el verano de 1949. Publ. Inst. Biol. Apl. 7: 155-157.

Margalef R. 1951a. Diversidad de especies en las comunidades naturales. Publ. Inst. Biol. Apl. 9: 83118.

Margalef R. 1951b. Plancton recogido por los laboratorios costeros. III- Plancton de las costas de Castellón durante el año 1950. Publ. Inst. Biol. Apl. 9: 4962.

Margalef R. 1951c. Ciclo anual del fitoplancton marino en la costa NE de la Península Ibérica. Publ. Inst. Biol. Apl. 9: 83-118.

Margalef R. 1953a. Estudios experimentales sobre las modificaciones inducidas por diferentes temperaturas en células de clorofíceas. Publ. Inst. Biol. Apl. 12: 5-78.

Margalef R. 1953b. Caracteres ligados a las magnitudes de los organismos y su significado sistemático y evolutivo. Publ. Inst. Biol. Apl. 12: 111-121.

Margalef R. 1953c. Los crustáceos de las aguas continentales ibéricas. Biología de las aguas continentales 10. Ministerio de Agricultura. Dirección General de Montes, Caza y Pesca Fluvial Instituto Forestal de Investigaciones y Experiencias, Madrid, $243 \mathrm{pp}$.

Margalef R. 1954a. Consideraciones sobre la determinación cuantitativa del fitoplancton por la valoración de pigmentos solubles y los factores que afectan a la relación entre cantidad de pigmento y peso seco. Publ. Inst. Biol. Apl. 16: 7184

Margalef R. 1954b. Un aparato para el cultivo de algas en condiciones regulables. Publ. Inst. Biol. Apl. 17: 65-69.

Margalef R. 1954c. Una técnica de filtración para el estudio cualitativo y cuantitativo del fitoplancton. Publ. Inst. Biol. Apl. 17: 131-134.

Margalef R. 1955. Temperatura, dimensiones y evolución. Publ. Inst. Biol. Apl. 19: 13-94.

Margalef R. 1956a. Cultivos experimentales de algas unicelulares. Inv. Pesq. 3: 3-19.

Margalef R. 1956b. Información y diversidad específica en las comunidades de organismos. Inv. Pesq. 3: 99-106.

Margalef R. 1956c. Rotíferos marinos del plancton de la ría de Vigo. Inv. Pesq. 4: 133-135.

Margalef R. 1956d. Paleoecología postglacial de la ría de Vigo. Inv. Pesq. 5: 89-112.

Margalef R. 1956e. Estructura y dinámica de la "purga de mar" en la ría de Vigo. Inv. Pesq. 5: 113-134.

Margalef R. 1957a. Fitoplancton de las costas de Puerto Rico. Inv. Pesq. 6: 39-52.

Margalef R. 1957b. Nuevos aspectos del problema de la suspensión en los organismos planctónicos. Inv. Pesq. 7: 105-116.

Margalef R. 1957c. Un modelo para el estudio de la distribución de organismos de gran dispersabilidad y área de reproducción muy localizada. Inv. Pesq. 7: 117-125.

Margalef R. 1957d. Fitoplancton de las costas de Blanes (Gerona) de Agosto de 1952 a Junio de 1956. Inv. Pesq. 8: 89-95.

Margalef R. 1957e. Variación local e interanual en la secuencia de las poblaciones de fitoplancton de red en las aguas superficiales de la costa mediterránea española. Inv. Pesq. 9: 65-95.

Margalef R. 1957f. La teoría de la información en ecología. Mem. Real Acad. Cienc. Artes Barcelona 32: 373-449.

Margalef R. 1958a. La sedimentación orgánica y la vida en los fondos fangosos de la ría de Vigo. Inv. Pesq. 11: 67-100.

Margalef R. 1958b. Information theory in ecology. Gen. Syst. 3: 36-71.

Margalef R. 1959. Pigmentos asimiladores extraídos de las colonias de celentéreos de los arrecifes de coral y su significado ecológico. Inv. Pesq. 15: 81-101.

Margalef R. 1961a. Velocidad de sedimentación de organismos pasivos del fitoplancton. Inv. Pesq. 18: 3-8.

Margalef R. 1961b. Hidrografía y fitoplancton de un área marina de la costa meridional de Puerto Rico. Inv. Pesq. 18: 33-96.

Margalef R. 1961c. Distribución ecológica y geográfica de las especies del fitoplancton marino. Inv. Pesq. 19: 81-101.

Margalef R. 1961d. Variaciones intraespecíficas de los pigmentos asimiladores en clorofíceas y fanerógamas acuáticas. Inv. Pesq. 19: $111-118$.

Margalef R. 1961e. Fitoplancton atlántico de las costas de Mauritania y Senegal. Inv. Pesq. 20: 131-143.

Margalef R. 1961f. Nouveaux développements dans la technique de l'extraction des pigments du phytoplancton. CIESM 16: 141-142.

Margalef R. 1963a. Desarrollo experimental de picnoclinas en pequeños volúmenes de agua. Inv. Pesq. 23: 3-10.

Margalef R. 1963b. Modelos simplificados del ambiente marino para el estudio de la sucesión y distribución del fitoplancton y del valor indicador de sus pigmentos. Inv. Pesq. 23: 11-52.

Margalef R. 1963c. Algunas regularidades en la distribución a escala pequeña y media de las poblaciones marinas de fitoplancton y en sus características funcionales. Inv. Pesq. 23: 169-230.

Margalef R. 1964a. Fitoplancton de las costas de Blanes (Provincia de Gerona, Mediterráneo occidental), de Julio de 1959 a Junio de 1963. Inv. Pesq. 26: 131-164.

Margalef R. 1964b. Modelos experimentales de poblaciones de fitoplancton: nuevas observaciones sobre pigmentos y fijación de carbono inorgánico. Inv. Pesq. 26: 195-203.

Margalef R. 1965. Distribución ecológica de las especies del fitoplancton marino en un área del Mediterráneo Occidental. Inv. Pesq. 28: 117-131.

Margalef R. 1966. Análisis y valor indicador de las comunidades de fitoplancton mediterráneo. Inv. Pesq. 30: 429-482.

Margalef R. 1967a. Correlaciones entre parámetros oceanográficos del Caribe. Inv. Pesq. 31: 1-15.

Margalef R. 1967b. Significado de las diferencias verticales de potencial eléctrico en el mar. Inv. Pesq. 31: 259-263.

Margalef R. 1967c. Un ejemplo de diversidad química. Inv. Pesq. 31: 489-490.

Margalef R. 1967d. Experiencias con contadores de seston en el crucero del "Mechelen", "Mediterranean outflow 1965", y formas de elaborar los resultados. Inv. Pesq. 31: 503-538.

Margalef R. 1967e. Las algas inferiores. In Mandazen P. (Hno. Ginés), Margalef R. (eds). Ecología marina. Fundación La Salle de Ciencias Naturales, Caracas, Venezuela, pp. 230-272.

Margalef R. 1968. Perspectives in Ecological Theory. The University of Chicago Press, Chicago. $111 \mathrm{pp}$.

Margalef R. 1969a. Composición específica del fitoplancton de la costa catalano-levantina (Mediterráneo Occidental) en 19621967. Inv. Pesq. 33: 345-380.

Margalef R. 1969b. Diversidad del fitoplancton de red en dos áreas del Atlántico. Inv. Pesq. 33: 275-286.

Margalef R. 1969c. Diversity and stability. A practical proposal and a model of interdependence. Brookhaven Symp. Biol. 22: 25-37.

Margalef R. 1970a. Seminario de Ecología Matemática. Inv. Pesq. 34: $1-8$.

Margalef R. 1970b. Diversidad y productividad del fitoplancton en el Mediterráneo Occidental. Inv. Pesq. 34: 565-573.

Margalef R. 1971a. Una campaña oceanográfica del "Cornide de Saavedra" en la región de afloramiento de NO Africano. Inv. Pesq. 35 (Suppl): 1-39.

Margalef R. 1971b. Distribución del fitoplancton entre Córcega y Barcelona, en relación con la mezcla vertical del agua, en Marzo de 1970. Inv. Pesq. 35 (2): 687-698.

Margalef R. 1972a. Editorial. Seminario sobre análisis factorial en ecología y taxonomía. Inv. Pesq. 36: 3-7. 
Margalef R. 1972b. Interpretaciones no estrictamente estadísticas de la representación de entidades biológicas en un espacio multifactorial. Inv. Pesq. 36: 183-190.

Margalef R. 1972c. Regularidades en la distribución de la diversidad del fitoplancton en un área del mar Caribe. Inv. Pesq. 36: 241-264.

Margalef R. 1973. Some critical remarks on the usual approaches to ecological modelling. Inv. Pesq. 37: 621-640.

Margalef R. 1978. Life-forms of phytoplankton as survival alternatives in an unstable environment. Oceanol. Acta 1: 493-509.

Margalef R. 1979. Alternative approaches in the modelling of populations. Inv. Pesq. 43: 337-350.

Margalef R. 1994. Through the looking glass: How marine phytoplakton appears through the microscope when graded by size and taxonomically sorted. Sci. Mar. 58: 87-101.

Margalef R. 1997a. Turbulence and marine life. In: Marrasé C., Saiz E., Redondo J.M. (eds), Lectures on plankton and turbulence. Sci. Mar. 61 (Suppl. 1): 109-123.

Margalef R. 1997b. Our Biosphere. Ecology Institute Ed., Oldendorf/Luhe, $176 \mathrm{pp}$.

Margalef R. 2001. The top layers of water bodies, a most important although relatively neglected piece of the biosphere plumbing. In: Gili J.M., Pretus J.L., Packard T.T. (eds), A Marine Science Odyssey into the 21st century. Sci. Mar. 65 (Suppl. 2): 207-213. https://doi.org/10.3989/scimar.2001.65s2207

Margalef R. 2004. Notes autobiogràfiques de Ramon Margalef López. Unpublished.

Margalef R., Andreu B. 1958. Componente vertical de los movimientos del agua en la ria de Vigo y su posible relación con la entrada de la sardina. Inv. Pesq. 11: 105-126.

Margalef R., Ballester A. 1967. Fitoplancton y producción primaria de la costa catalana, de Junio de 1965 a Junio de 1966. Inv. Pesq. 31: 165-182.

Margalef R., Blasco D. 1970. Influencia del puerto de Barcelona sobre el fitoplancton de las áreas vecinas: Una mancha de plancton de gran densidad, con dominancia de Thalassiosira, observada en agosto de 1969. Inv. Pesq. 34: 575-580.

Margalef R., Castellví J. 1967. Fitoplancton y producción primaria de la costa catalana, de Julio de 1966 a Julio de 1967. Inv. Pesq. 31: 491-502.

Margalef R., Duran M. 1953. Microplancton de Vigo, de octubre de 1951 a septiembre de 1952. Publ. Inst. Biol. Apl. 13: 5-78.

Margalef R., Estrada M. 1971. Simple approaches to a pattern analysis of phytoplankton. Inv. Pesq. 35 (1): 269-297.

Margalef R., Estrada M. 1987. Synoptic distribution of summer microplankton (Algae and Protozoa) across the principal front in the Western Mediterranean. Inv. Pesq. 51: 121-140.

Margalef R., González Bernáldez F. 1969. Grupos de especies asociadas en el fitoplancton del Mar Caribe (NE de Venezuela). Inv. Pesq. 33: 287-312.

Margalef R., Herrera J. 1961. El nivel del mar en Castellón. Inv. Pesq. 19: 55-63.

Margalef R., Herrera J. 1963. Hidrografía y fitoplancton de las costas de Castellón, de Julio de 1959 a Junio de 1960. Inv. Pesq. 22: 49-109.

Margalef R., Herrera J. 1964. Hidrografía y fitoplancton de la costa comprendida entre Castellón y la desembocadura del Ebro, de Julio de 1961 a Julio de 1962. Inv. Pesq. 26: 49-90.

Margalef R., Herrera J. 1966. La producción primaria en las aguas del puerto de Barcelona. Inv. Pesq. 30: 45-48.

Margalef R., Morales E. 1960. Fitoplancton de las costas de Blanes (Gerona), de Julio de 1956 a Junio de 1959. Inv. Pesq. 16: 3-31.

Margalef R., Saiz F., Rodríguez-Roda J., et al. 1952. Plancton recogido por los laboratorios costeros, V.- Fitoplancton de las costas de Castellón durante el año 1951. Publ. Inst. Biol. Apl. 10: $133-143$.

Margalef R., Herrera J., Rodríguez-Roda J., et al. 1954. Plancton recogido por los laboratorios costeros. VIII.- Fitoplancton de las costas de Castellón durante el año 1952. Publ. Inst. Biol. Apl. 17: 87-100.

Margalef R., Durán M., Saiz F. 1955. El fitoplancton de la ría de Vigo de enero de 1953 a marzo de 1954. Inv. Pesq. 2: 85-130.

Margalef R., Muñoz F., Herrera J. 1957. Fitoplancton de las costas de Castellón de Enero de 1955 a Junio de 1956. Inv. Pesq. 7: 3-31.

Margalef R., Herrera J., Arias E. 1959. Hidrografía y fitoplancton de las costas de Castellón, de Julio de 1957 a Junio de 1958. Inv. Pesq. 15: 3-38.

Marrasé C., Costello J.H., Granata T., et al. 1990. Grazing in a turbulent environament: energy dissipation, encounter rates, and efficacy of feeding corrents in Centropages hamatus. Proc. Natl. Acad. Sci. USA 87: 1653-1657. https://doi.org/10.1073/pnas.87.5.1653

Massutí M., Margalef R. 1950. Introducción al estudio del plancton marino. Patronato Juan de la Cierva de Investigación Científica y Técnica, CSIC, Barcelona, $182 \mathrm{pp}$.

Muñoz F., Herrera J., Margalef R. 1956. Fitoplancton de las costas de Castellón durante el año 1954. Inv. Pesq. 3: 75-90.

Peters F. 2010. Ramon Margalef, the curiosity driven life of a selftaught naturalist. ASLO, Waco, USA, 80 pp. https://doi.org/10.1002/lob.20101911

Peters F., Marrasé C., Havskum H., et al. 2002. Turbulence and the microbial food web: effects on bacterial losses to predation and on community structure. J. Plankton Res. 24: 321-331. https://doi.org/10.1093/plankt/24.4.321

Rodríguez-Roda J., Larrañeta M.G., Margalef R., et al. 1951. Datos para una crítica del significado de la media vertebral de las poblaciones de la sardina (Sardina pilchardus Walb.). Publ. Inst. Biol. Apl. 9: 185-192.

Saiz E., Alcaraz M., Paffenhöfer G.A. 1992. Effects of small-scale turbulence on feeding rate and gross-growth efficiency of three Acartia species (Copepoda: Calanoida). J. Plankton Res. 14: 1085-1097. https://doi.org/10.1093/plankt/14.8.1085

Segarra D. 2019. Les "idees dibuixades" de Ramon Margalef. Butlletí CREAF, Especial, Novembre 2019.

h t t p : / / b log.creaf.cat/con e i e m e n t / les-idees-dibuixades-de-ramon-margalef/

Shannon C.E., Weaver W. 1949. The Mathematical Theory of Communication. University of Illinois Press.

Tufte E. 1983. The Visual Display of Quantitative Information. Graphics Press, Cheshire, Connecticut, pp. 13. 